\title{
Article \\ Green Synthesis of Zinc Oxide Nanoparticles (ZnO-NPs) Using Arthrospira platensis (Class: Cyanophyceae) and Evaluation of their Biomedical Activities
}

\author{
Ehab F. El-Belely ${ }^{1} \oplus$, Mohamed M. S. Farag ${ }^{1}$, Hanan A. Said ${ }^{2}$, Abeer S. Amin ${ }^{3}$, Ehab Azab ${ }^{4,5}{ }^{\circledR}$, Adil A. Gobouri ${ }^{6}$ \\ and Amr Fouda $1, *(1)$ \\ 1 Botany and Microbiology Department, Faculty of Science, Al-Azhar University, Cairo 11884, Egypt; \\ elbelely@azhar.edu.eg (E.F.E.-B.); mohamed.farag@azhar.edu.eg (M.M.S.F.) \\ 2 Botany Department, Faculty of Science, Fayoum University, Fayoum 63511, Egypt; hah01@fayoum.edu.eg \\ 3 Botany Department, Faculty of Science, Suez Canal University Ismailia, Ismailia 41522, Egypt; \\ abeeramin2003@yahoo.com \\ 4 Department of Biotechnology, College of Science, Taif University, P.O. Box 11099, Taif 21944, Saudi Arabia; \\ e.azab@tu.edu.sa \\ 5 Botany and Microbiology Department, Faculty of Science, Zagazig University, Zagazig 44519, Egypt \\ 6 Department of Chemistry, College of Science, Taif University, P.O. Box 11099, Taif 21944, Saudi Arabia; \\ a.gobouri@tu.edu.sa \\ * Correspondence: amr_fh83@azhar.edu.eg; Tel.: +20-111-335-1244
}

check for

updates

Citation: El-Belely, E.F.; Farag, M.M.S.; Said, H.A.; Amin, A.S.; Azab, E.; Gobouri, A.A.; Fouda, A. Green Synthesis of Zinc Oxide Nanoparticles (ZnO-NPs) Using Arthrospira platensis (Class: Cyanophyceae) and Evaluation of their Biomedical Activities. Nanomaterials 2021, 11, 95. https: / / doi.org/10.3390/nano 11010095

Received: 1 December 2020 Accepted: 30 December 2020 Published: 4 January 2021

Publisher's Note: MDPI stays neutral with regard to jurisdictional clai$\mathrm{ms}$ in published maps and institutional affiliations.

Copyright: (C) 2021 by the authors. Licensee MDPI, Basel, Switzerland. This article is an open access article distributed under the terms and conditions of the Creative Commons Attribution (CC BY) license (https:// creativecommons.org/licenses/by/ $4.0 /)$.

\begin{abstract}
In this study, zinc oxide nanoparticles (ZnO-NPs) were successfully fabricated through the harnessing of metabolites present in the cell filtrate of a newly isolated and identified microalga Arthrospira platensis (Class: Cyanophyceae). The formed ZnO-NPs were characterized by UV-Vis spectroscopy, Fourier transform infrared (FT-IR), transmission electron microscopy (TEM), energydispersive spectroscopy (EDX), X-ray diffraction (XRD), and X-ray photoelectron spectroscopy (XPS). Data showed the efficacy of cyanobacterial metabolites in fabricating spherical, crystallographic ZnONPs with a size $\approx 30.0$ to $55.0 \mathrm{~nm}$ at a wavelength of $370 \mathrm{~nm}$. Moreover, FT-IR analysis showed varied absorption peaks related to nanoparticle formation. XPS analysis confirms the presence of $\mathrm{Zn}$ (II)O at different varied bending energies. Data analyses exhibit that the activities of biosynthesized ZnO-NPs were dose-dependent. Their application as an antimicrobial agent was examined and formed clear zones, $24.1 \pm 0.3,21.1 \pm 0.06,19.1 \pm 0.3,19.9 \pm 0.1$, and $21.6 \pm 0.6 \mathrm{~mm}$, at $200 \mathrm{ppm}$ against Bacillus subtilis, Staphylococcus aureus, Pseudomonas aeruginosa, Escherichia coli, and Candida albicans, respectively, and these activities were reduced as the NPs concentration decreased. The minimum inhibitory concentration (MIC) values were determined as $50 \mathrm{ppm}$ for S. aureus, $25 \mathrm{ppm}$ for P. aeruginosa, and $12.5 \mathrm{ppm}$ for B. subtilis, E. coli, and C. albicans. More interestingly, ZnO-NPs exhibit high in vitro cytotoxic efficacy against cancerous (Caco-2) $\left(\mathrm{IC}_{50}=9.95 \mathrm{ppm}\right)$ as compared with normal (WI38) cell line $\left(\mathrm{IC}_{50}=53.34 \mathrm{ppm}\right)$.
\end{abstract}

Keywords: cyanobacteria; Arthrospira platensis; ZnO-NPs; antimicrobial; in vitro cytotoxicity

\section{Introduction}

Nanotechnology is a multidisciplinary science concerning producing novel materials at the nano-scale size (1-100 nm), which can be integrated into various applications [1] At the nanoscale, the materials acquired new features such as large surface area, thermal conductivity, size, charge, shape, crystal structure, surface morphology, and zeta potential, which enables them to integrate into biomedical and biotechnological sectors [2-4]. Nanoparticles (NPs) can be fabricated by different methods including chemical, physical, and biological methods. The former chemical and physical methods utilized hazardous material, needed harsh conditions such as temperature, energy, and pressure, and they can produce hazardous by-products $[2,5]$. Therefore, the interest increased in biological methods or green nanotechnology. 
Green nanotechnology means a clean method utilized for the synthesis of nanomaterials by eliminating or decreasing hazardous materials used during the fabrication process [6]. The green synthesis of NPs can be accomplished using various biological entities such as bacteria, actinomycetes, fungi, cyanobacteria, macro-algae, and plants [7]. Green synthesis is preferred over chemical and physical methods because of its eco-friendly, cost-effectiveness, easy handling, upscaling, and biocompatibility [6]. Recently, several NPs are synthesized by green methods such as $\mathrm{Ag}, \mathrm{Au}, \mathrm{Cu}, \mathrm{CuO}, \mathrm{ZnO}, \mathrm{Se}$, and others that are integrated into different biological activities [8-10]. Biogenic or green synthesized nanoparticles offer a promising alternative antimicrobial and anticancer agent for more safe, specific, and economic drugs or drug vehicle in drug delivery.

The biogenic synthesis of zinc oxide nanoparticles (ZnO-NPs) by biological entities are attributed to the presence of different metabolites including proteins, enzymes, and other biomolecules that act as reducing, capping, and stabilizing agents. The different shape, size, dispersity of $\mathrm{ZnO}-\mathrm{NPs}$, and stability are related to the secreted metabolites [11]. The extracellular mechanisms of ZnO-NPs can be accomplished by the reductase enzyme secreted by microbes in growth media. NADH (Nicotinamide Adenine Dinucleotide plus hydrogen ion)-dependent reductase enzymes serve as electron carriers to reduce $\mathrm{Zn}^{2+}$ to $\mathrm{Zn}^{\circ}$, which subsequently forms $\mathrm{ZnO}-\mathrm{NPs}$ [12]. The reductase enzymes obtained electrons from $\mathrm{NADH}$ that oxidized after that to $\mathrm{NAD}^{+}$; at the same time, metal ions reduced to nanoscales.

Zinc oxide nanoparticles ( $\mathrm{ZnO}-\mathrm{NPs}$ ) are considered the most significant between the metal oxides NPs due to their unique chemical and physical properties, which hence increase their applicability aspects [13]. ZnO-NPs can be integrated into the rubber industry because they furnish wearproof composites and increase the intensity and toughness of the rubber [14]. In addition, ZnO-NPs interweave with sunscreen and cosmetic care products due to their highly UV-adsorption properties [15]. Moreover, due to the unique properties that arise at the nanoscale structure such as high electron mobility, wide bandgap, and high visible transparency, $\mathrm{ZnO}-\mathrm{NPs}$ are considered a good semiconductor. In the textile industry, $\mathrm{ZnO}-\mathrm{NPs}$ are added to finished fabrics to increase their resistance to ultraviolet rays, antibacterial, and deodorant activities [16]. As a part of the applications, ZnO-NPs can be used for antifungal, concrete production, solar cell, electronics, photocatalysis, and electrotechnology industries $[17,18]$. Recently, ZnO-NPs have been validated as additives to dietary products to improve the growth performance, enhance the antioxidant property and immune response, and increase the quality of eggs and improve the production of layer chickens [19].

Zinc is an essential trace present in all body tissues, in addition to being a constant part of most enzyme systems, so it participates in the body's metabolism process and is assimilated during nucleic acid and protein synthesis, nervous cell synthesis, and hematopoiesis [17]. At the nanoscale, $\mathrm{ZnO}-\mathrm{NPs}$ can be adsorbed easily especially at a small size. Interestingly, $\mathrm{ZnO}-\mathrm{NPs}$ can be used in the food industry as additives, especially since they are recommended as a safe substance by the FDA (Food and Drug Administration) [20], meaning that they have safe applicability for human and animals.

Cyanophyceae are a group of prokaryotic structured cells that possess carbon dioxidedependent photosynthesis [21]. They are considered a good source for the extracellular and intracellular synthesis of NPs due to their potential to produce a huge number of metabolites [21]. Various NPs are fabricated through harnessing metabolites of cyanobacteria such as Ag, Au, Pt, and Pd-NPs [22,23]. The most common cyanobacterial species used for the fabrication of NPs are Spirulina spp. and Nostoc spp. due to the high contents of bioactive substances [24]. Amongst cyanobacterial species, Arthrospira platensis, previously called Spirulina, is a planktonic multicellular filamentous cyanobacterium that commonly grows in subtropical, alkaline fresh, and marine aquatic habitats. The edible biomass of $A$. platensis is a rich source of nutraceutical and pharmaceutical biomolecules such as proteins, vitamins, pigments, and polysaccharides as well as minerals [25], and it frequently can be used for the ecofriendly biogenic synthesis of metallic and metal oxide 
nanoparticles by either extracellular or intracellular mechanisms. Moreover, the rapid growth rates, avoidance of contaminations as no complicated nutrients were added to the media, and low cost of biomass production make $A$. platensis a promising source for the biosynthesis of nanoparticles. [26].

This study aims to investigate the fabrication of $\mathrm{ZnO}-\mathrm{NPs}$ using a newly isolated and characterized microalga, $A$. platensis. Characterizing the green biosynthesized NPs using UV-Vis spectroscopy, Fourier transform infrared (FT-IR), XRD, TEM, energy-dispersive spectroscopy (EDX), and XPS analyses is another major goal. In addition, evaluation of the biological activities of green synthesized ZnO-NPs including antimicrobial activity against pathogenic Gram-positive and Gram-negative bacteria as well as unicellular fungi and investigating their in vitro cytotoxic effect against normal and cancerous cells were investigated for possible application in the biomedical field.

\section{Materials and Methods}

\subsection{Isolation, Purification, and Identification of Cyanobacterial Strain}

The cyanobacterial strain was isolated from a water sample collected from EL-Kanater El-Khairia, Dakahlia governorate, Egypt, and transferred directly to Algal Lab., Botany and Microbiology Department, Faculty of Science, Al-Azhar University, Cairo, Egypt. The isolation procedure was achieved by cultivated in Zarrouk's media and incubated at $30 \pm 1{ }^{\circ} \mathrm{C}$ with a photoperiod $8 / 16 \mathrm{~h}$ of dark/light cycle using cool-white, fluorescent lamps at 3000 Lux of light intensity. The appeared colony was checked for purity, and the purified isolate was preserved for further study. The morphological characteristics were examined using a light microscope, which was used to check the purity, shape, color, and structure of cyanobacterial isolate. The microscopic taxonomy was achieved according to Edlund [27].

On the other hand, the molecular identification based on 16S rRNA of cyanobacterial strain was achieved as the following: genomic DNA of cyanobacteria sp. was extracted according to the method recommended by Miller et al. [28]. Briefly, purified colonies were resuspended in $50 \mu \mathrm{L}$ of sterile deionized $\mathrm{H}_{2} \mathrm{O}$. The cyanobacterial cell suspension is heated in a water bath at $97^{\circ} \mathrm{C}$ for $10 \mathrm{~min}$; after that, it was centrifuged at 15,000 rpm for $10 \mathrm{~min}$, and the cyanobacterial cell lysate containing the DNA was obtained. Then, $16 S$ rRNA was amplified in a polymerase chain reaction (PCR) using the genomic DNA as a template and universal primers, 27f (5-AGAGTTTGATCCTGGCTCAG-3) and 1492r (5-GGTTACCTTGTTACGACTT-3) [29]. The PCR mixture $(50 \mu \mathrm{L})$ contained the following: $1 \times$ PCR buffer, $0.5 \mathrm{mM} \mathrm{MgCl}_{2}, 2.5 \mathrm{U}$ Taq DNA polymerase (QIAGEN), $0.25 \mathrm{mM} \mathrm{dNTP,}$ $0.5 \mu \mathrm{M}$ of each primer, and $1 \mu \mathrm{L}$ of extracted cyanobacterial genomic DNA.

The PCR was analyzed in a DNA Engine Thermal Cycler by Sigma Scientific Services Company (Cairo, Egypt) with a hot starting at $94{ }^{\circ} \mathrm{C}$ for $3 \mathrm{~min}$, followed by 30 cycles of $94{ }^{\circ} \mathrm{C}$ for $30 \mathrm{~s}, 55^{\circ} \mathrm{C}$ for $30 \mathrm{~s}$, and $72{ }^{\circ} \mathrm{C}$ for $1 \mathrm{~min}$, followed by a final extension at $72{ }^{\circ} \mathrm{C}$ for $10 \mathrm{~min}$. Sequencing was conducted using ABI 3730x1 DNA sequencer at GATC Company (Konstanz, Germany). The obtained sequences were compared against the Gene Bank database using the NCBI BLAST (Basic Local Alignment Search) program. Then, sequences were compared with 16S rRNA in the Gene Bank database using BLASTN, and phylogenetic trees were conducted by bootstrap analysis.

\subsection{Cyanobacterial Mediated Green Synthesis of ZnO-NPs}

2.2.1. Biomass Preparation

The cyanobacterium strain, A. platensis (EF), was grown in Zarrouk's medium supplied with filtered air under the previously mentioned condition to prepare cyanobacterial biomass.

\subsubsection{Cell Filtrate-Mediated Biosynthesis of ZnO-NPs}

Microalga biomass was utilized in the logarithmic phase. The cultivated strain was subjected to a centrifugation process to separate the microalga biomass and then washed thrice with double-distilled deionized water to remove any medial components. After 
that, the washed biomass (15 g) was mixed with $100 \mathrm{~mL}$ of distilled water for $48 \mathrm{~h}$ and underwent a centrifugation process to collect the biomass filtrate (supernatant without any biomass). $\mathrm{ZnO}$ nanoparticles were synthesized as follows: $0.44 \mathrm{~g}$ of $\mathrm{Zn}\left(\mathrm{CH}_{3} \mathrm{COO}\right)_{2}$. $2 \mathrm{H}_{2} \mathrm{O}$ was dissolved in two $\mathrm{mL}$ of distilled $\mathrm{H}_{2} \mathrm{O}$; after that, $98 \mathrm{~mL}$ of biomass filtrated was added to get a final concentration of $2 \mathrm{mM}$. The mixture was incubated for $24 \mathrm{~h}$ at $30{ }^{\circ} \mathrm{C} \pm 2{ }^{\circ} \mathrm{C}$ and $150 \mathrm{rpm}$ shaking condition. The resultant white precipitate was collected and oven-dried at $200{ }^{\circ} \mathrm{C}$ for $24 \mathrm{~h}$ [30] to obtain ZnO-NPs as a powder, which was used after that for further study.

\subsection{Characterization of Green Synthesized $\mathrm{ZnO}-\mathrm{NPS}$}

\subsubsection{Ultraviolet-Visible (UV-Vis) Spectra}

The formation of $\mathrm{ZnO}-\mathrm{NPs}$ was investigated by mixture solutions color changes. The green synthesized ZnO-NPs in a colloid solution was also monitored by UV-Vis spectra, as it showed an intense absorption peak due to surface plasmon excitation. Color changes in the mixture of cyanobacterial extract $/ \mathrm{Zn}\left(\mathrm{CH}_{3} \mathrm{CO}_{2}\right)_{2}$ solutions were measured by Spectrophotometry (JENWAY 6305 Spectrophotometer, 230 V/50 Hz, Staffordshire, UK), at wavelengths of 200-800 nm. The cyanobacterial extract without $\mathrm{Zn}\left(\mathrm{CH}_{3} \mathrm{CO}_{2}\right)_{2}$ was used as the blank.

\subsubsection{Fourier Transform Infrared Spectroscopy (FT-IR)}

The functional groups present in green synthesized $\mathrm{ZnO}-\mathrm{NPs}$ were analyzed by FT-IR analysis (JASCO FT-IR 4100 spectrometer, Hachioji, Tokyo, Japan). About 0.2 g of ZnO-NPs powder was mixed with potassium bromide $(\mathrm{KBr})$ and loaded onto a disc at high pressure. The FT-IR spectra were scanned at a resolution of $4.0 \mathrm{~cm}^{-1}$ at a wavelength of $400-4000 \mathrm{~cm}^{-1}$.

\subsubsection{Transmission Electron Microscopy (TEM) and Energy Dispersive Spectroscopy (EDX)}

The morphological analysis including the shape and size of cyanobacterial mediated biosynthesized of ZnO-NPs were examined by TEM (JEM-1230, JEOL, Tokyo, Japan). The sample was prepared by adding a drop of colloidal ZnO-NPs solution on a copper grid covered by an amorphous carbon film and desiccating the solvent under vacuum overnight before loading onto a specimen holder. AMT software was calibrated for NPs size measurements by a digital TEM camera. The average size of the fabricated ZnO-NPs was calculated from measuring over 100 nanoparticles in at least 10 random locations on the TEM grid in enlarged microphotographs.

The elemental structures of the green synthesized ZnO-NPs were measured by SEM (JEOL JSM-6360LA, Tokyo, Japan), which was connected with an energy-dispersive spectroscope (EDX, Tokyo, Japan) to detect the surface shape and elemental compositions of different the NPs [31].

\subsubsection{X-ray Diffraction (XRD) Patterns}

The crystalline nature of the ZnO-NPs synthesized by cyanobacterium species was detected by X-ray diffraction (XRD, X'Pert Pro Philips, Dandong, China) at the following operation system: $\mathrm{CuK} \alpha$ radiation, the $2 \theta$ angle was in a range from $0^{\circ}$ to $90^{\circ}, \lambda=1.540 \AA$ (Eindhoven, Netherlands). The voltage and current were adjusted to $40 \mathrm{kV}$ and $30 \mathrm{~mA}$, respectively. The average nanoparticle size was calculated using the following the DebyeScherrer Equation (1) [32], shown below:

$$
D=0.9 \lambda / \beta \operatorname{Cos} \theta
$$

where $D$ is the average nanoparticle size and 0.9 is the Scherrer's constant. $\lambda, \beta$, and $\theta$ are the X-ray wavelength, Full-Width Half Maximum, and the Bragg's angle, respectively.

\subsubsection{X-ray Photoelectron Spectroscopy (XPS) Analysis}

ESCALAB 250XI (Thermo Fischer Scientific Inc., Waltham, MA, USA) equipped with a monochromatic X-ray $\mathrm{Al} \mathrm{K} \alpha$ radiation $(1486.6 \mathrm{eV})$ was used for the XPS analysis. For the 
analysis, the samples were prepared under the pressure of $10^{-8} \mathrm{mbar}$, and the energy was calibrated with an $\mathrm{Ag} 3 d_{5 / 2}$ signal $(\triangle \mathrm{BE}: 0.45 \mathrm{eV})$ and $\mathrm{C} 1 \mathrm{~s}$ signal $(\triangle \mathrm{BE}: 0.82 \mathrm{eV})$. The size of the spot was $500 \mu \mathrm{m}$ and the full and narrow-spectrum pass energies were 50 and $20 \mathrm{eV}$, respectively $[33,34]$.

\subsection{Biological Activities of Cyanobacterium-Mediated Green Synthesis of ZnO-NPs}

2.4.1. Antimicrobial Activity

The antimicrobial efficacy of green synthesized ZnO-NPs formed through the harnessing of cyanobacterium metabolites was assessed by the agar well diffusion method against prokaryotic and eukaryotic pathogenic species. The prokaryotic species are represented by Gram-positive bacteria (Staphylococcus aureus ATCC6538 and Bacillus subtilis ATCC6633) and Gram-negative bacteria (Escherichia coli ATCC8739 and Pseudomonas aeruginosa ATCC9022), while eukaryotic pathogenic microbe represented by unicellular fungi Candida albicans ATCC10231. Briefly, each bacterial and unicellular fungal strains ( $100 \mu \mathrm{L} / 1.0$ O.D.) were seeded on $100 \mathrm{~mL}$ of Mueller Hinton agar media under aseptic condition. After that, $100 \mu \mathrm{L}$ of stock $\mathrm{ZnO}-\mathrm{NPs}$ solution $(200 \mathrm{ppm})$ was put into well $(0.7 \mathrm{~mm})$ on Mueller-Hinton agar plates. To detect the minimum inhibitory concentration of ZnO-NPs (MIC) for each tested organism, different concentrations $(150,100,50,25,12.5$, and $6.25 \mathrm{ppm})$ were prepared. The inoculated plates were kept in the refrigerator for about $2 \mathrm{~h}$ and transferred to the incubator at $35^{\circ} \mathrm{C} \pm 2{ }^{\circ} \mathrm{C}$ for $24 \mathrm{~h}$. The results were as the diameter of inhibition zones $(\mathrm{mm})$ around each well [35]. The experiment was done in triplicate.

\subsubsection{In Vitro Cytotoxic Efficacy of ZnO-NPs Synthesized by Cyanobacterium Species}

The human WI38 cell line (lung normal cell line) and Caco-2 cancer cell (human colorectal adenocarcinoma cells) were obtained from the American Type Culture Collection (ATCC, Manassas, VA, USA). The efficacy of cyanobacterium-mediated ZnO-NPs synthesis as cytotoxic effects was assessed using an MTT (3-(4,5-dimethylthiazol-2-yl)-2,5-diphenyl tetrazolium bromide) assay against the previous normal WI38 cells and Caco-2. Briefly, the cells were inoculated in 96-well microtiter plates at $1 \times 10^{5}$ cells/well followed by treatment with double-fold dilution (200-6.25 ppm) of the $\mathrm{ZnO}-\mathrm{NPs}$ and incubated at $37^{\circ} \mathrm{C}$ for $48 \mathrm{~h}$. After that, the MTT ( $5 \mathrm{mg} \mathrm{mL}^{-1}$ in phosphate-buffered saline) was added to each inoculated well and incubated for $1-5 \mathrm{~h}$ at $37^{\circ} \mathrm{C}$ and $5 \% \mathrm{CO}_{2}$. At the end of the incubation period, the purple formazan crystals were formed, which were further dissolved by adding DMSO (10\%). The plates were agitated using a plate shaker for $30 \mathrm{~min}$ in dark conditions. Ultimately, the color intensity of samples was measured at $560 \mathrm{~nm}$ using a multi-well ELISA plate reader [36]. The cell viability percentage was calculated as follows.

$$
\text { Cell viability }(\%)=\frac{\text { Absorbance of treated sample }}{\text { Absorbance of control }} \times 100
$$

\subsection{Statistical Analysis}

One-way analysis of variance (ANOVA) was used to investigate the efficacy of ZnO-NPs as antimicrobial and in vitro cytotoxicity. A posteriori pairwise-multiple comparisons were done using Tukey's range tests at $\alpha=0.05$. All results are the means of three independent replicates. Data were statistically analyzed using SPSS v17 (SPSS Inc., Chicago, IL, USA).

\section{Results and Discussion}

\subsection{Identifications of Cyanophyceae Strain}

The light microscope confirms the purity of the isolate, which appeared as a filamentous structure, and the helix, which was open left-handed (Figure 1A). The gene sequence analysis revealed that the cyanobacterial isolate was related to Arthrospira platensis (accession number: NR125711) with a similarity percent of $99.55 \%$. The obtained sequence retrieved from this study was a deposit in GeneBank under accession number MW115140. Therefore, the selected cyanobacterial strain was identified as Arthrospira platensis strain (EF) (Figure 1B). 


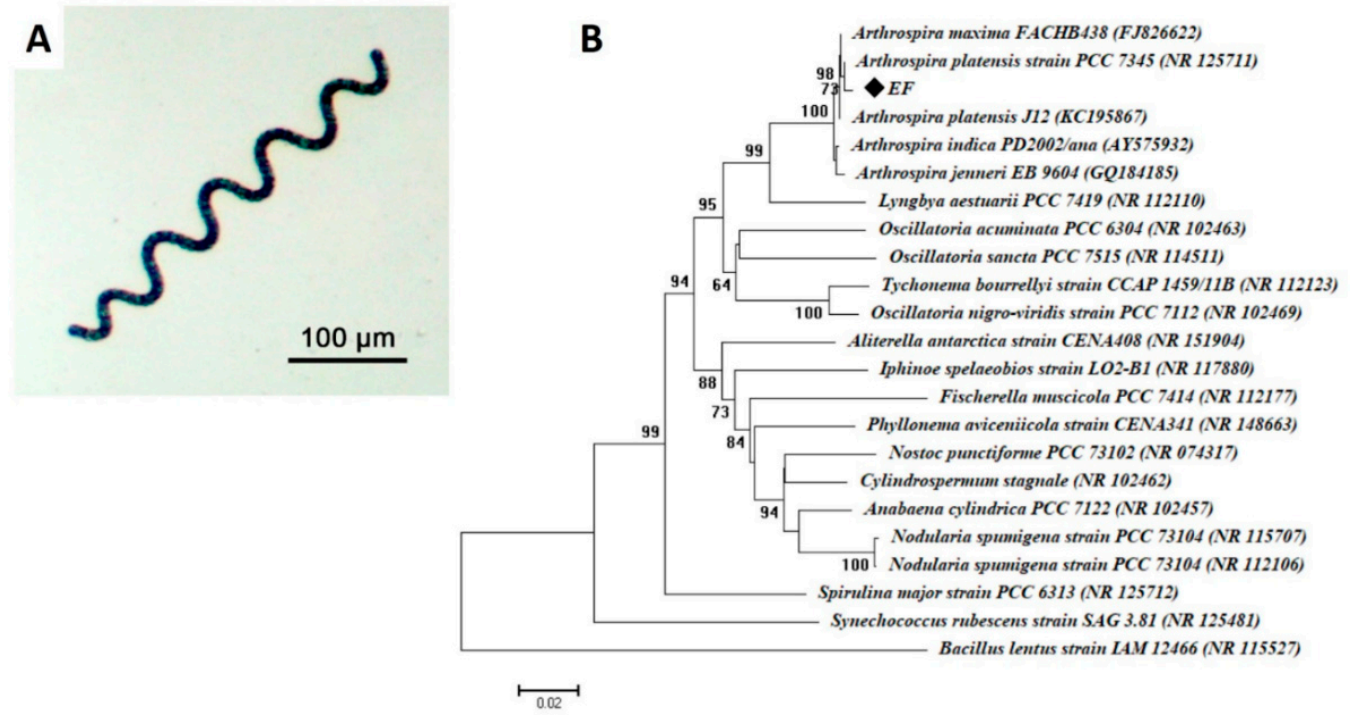

Figure 1. Microscopic and molecular identification of cyanobacteria Arthrospira platensis strain (EF). (A) denotes a typical single trichome of $A$. platensis (Class: Cyanophyceae); (B) denotes a phylogenetic analysis of $16 \mathrm{~S}$ rRNA sequences of cyanobacterial strain with reference sequences from NCBI. refers to $16 \mathrm{~S}$ rRNA sequences of $A$. platensis. The analysis was performed in MEGA6 using the neighbor-joining method.

\subsection{Arthrospira Platensis Mediated Biosynthesis of $\mathrm{ZnO}-\mathrm{NPs}$}

The biosynthesis of $\mathrm{ZnO}-\mathrm{NPs}$ was based on reducing, capping, and stabilizing of precursor $\left(\mathrm{Zn}\left(\mathrm{CH}_{3} \mathrm{COO}\right)_{2} \cdot 2 \mathrm{H}_{2} \mathrm{O}\right)$ by metabolites involved in the cell filtrate of $A$. platensis which contains polysaccharide, proteins, and enzymes (Figure 2). The function of capping agents was preventing the biosynthesis of hydrated $\mathrm{ZnO}$. In this study, the green synthesis of $\mathrm{ZnO}-\mathrm{NPs}$ was achieved by mixing $2 \mathrm{mM}$ of the precursor with $100 \mathrm{~mL}$ of A. platensis cell filtrate and incubated at $150 \mathrm{rpm}$ shaking state at room temperature. The as-formed white precipitate was collected and calcinated at $200{ }^{\circ} \mathrm{C}$ for $24 \mathrm{~h}$.

$$
\mathrm{Zn}\left(\mathrm{CH}_{3} \mathrm{COO}\right)_{2} \cdot 2 \mathrm{H}_{2} \mathrm{O} \stackrel{\text { A. platensis cell filtrate }}{\longrightarrow} \mathrm{Zn}(\mathrm{II}) \mathrm{O}
$$

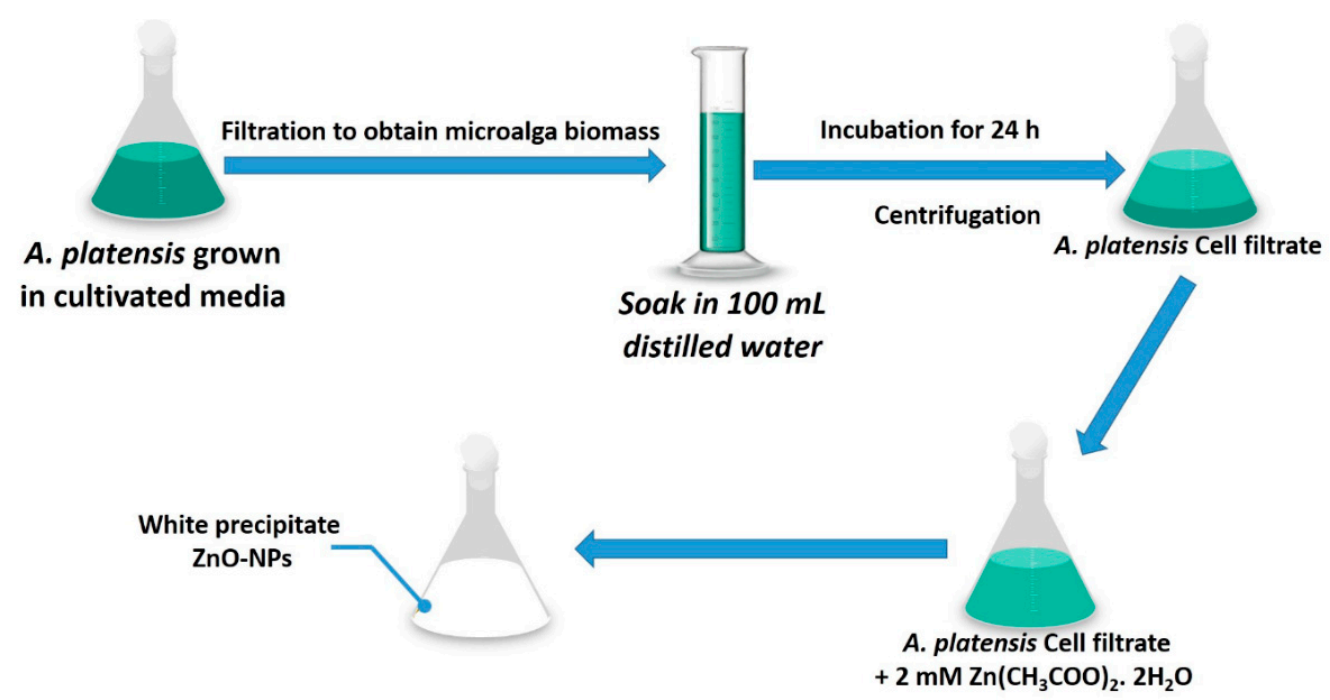

Figure 2. Flowchart of green synthesis zinc oxide nanoparticles (ZnO-NPs) by cyanobacterial A. platensis. 


\subsection{Characterization of Green Synthesized ZnO-NPs}

\subsubsection{UV-Vis Spectroscopic Analysis}

The first indicator for $\mathrm{ZnO}-\mathrm{NPs}$ formation is visual observation followed by measuring this change by UV at various wavelengths $(200$ to $800 \mathrm{~nm})$ to detect the surface plasmon resonance (SPR). In this study, the color of the cyanobacterial extract was changed to turbid white after adding zinc acetate as a precursor for ZnO-NPs. Figure 3A showed that the UV-Vis spectra of green synthesized ZnO-NPs demonstrated a significant peak of $370 \mathrm{~nm}$, which is mostly distinguished by ZnO-NPs. The obtained results are completely consistent with Singh et al. [37], who reported the efficacy of Anabaena strain L3 to fabricate ZnO-NPs and exhibit intense SPR at $370 \mathrm{~nm}$. These findings are incompatible with our previous study of biosynthesized ZnO-NPs using fungal strains Fusarium keratoplasticum A1-3 and Aspergillus niger G3-1, which exhibit SPR at $390 \mathrm{~nm}$ [38]. Vennila and Jesurani [39] reported that the SPR of green synthesized ZnO-NPs was mostly in the wavelength range between 370 and $400 \mathrm{~nm}$.
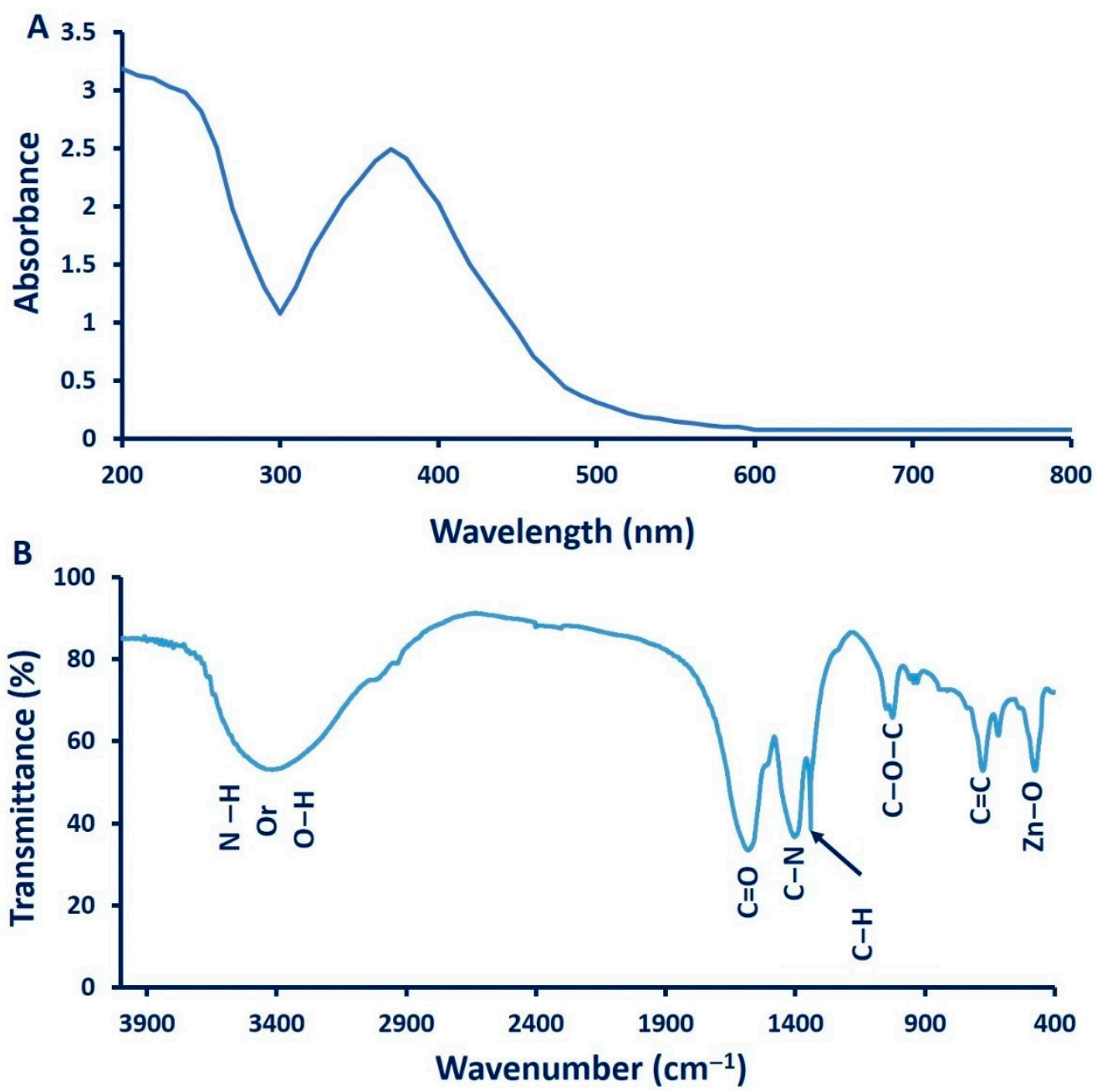

Figure 3. Characterization of green synthesized ZnO-NPs by A. platensis. (A) UV-Vis spectra, (B) Fourier transform infrared (FT-IR) analysis.

\subsubsection{Fourier Transform Infrared Spectroscopy (FT-IR) Analysis}

The functional groups, as well as the chemical structures of A. platensis-mediated ZnO-NPs synthesis was determined by FT-IR analysis (Figure 3B). The FT-IR spectra exhibit seven intense peaks at 3415, 1600,1410,1341, 1025, 676, and $503 \mathrm{~cm}^{-1}$. The broad absorption peak at $3415 \mathrm{~cm}^{-1}$ is related to $\mathrm{N}-\mathrm{H}$ overlapped with a stretching $\mathrm{O}-\mathrm{H}$ 
band [33]. The breadth of this broad peak could be attributed to the formation of intraand intermolecular hydrogen bonds [40]. The low-intensity peak observed at $3000 \mathrm{~cm}^{-1}$ is related to the stretching $\mathrm{CH}_{2}$ of asymmetric and symmetric carbohydrates and/or lipids [41], whereas the band at $1600 \mathrm{~cm}^{-1}$ is corresponding to the stretching $\mathrm{C}=\mathrm{O}$ vibration of proteins [42] or remaining acetate. The absorption wave of $\mathrm{CH}_{2}$ or $\mathrm{CH}_{3}$ of proteins is responsible for the vibration bending of the $\mathrm{C}-\mathrm{H}$ at wavenumber $1341 \mathrm{~cm}^{-1}$ [40]. The observed band at $1410 \mathrm{~cm}^{-1}$ has corresponded to the $\mathrm{C}-\mathrm{N}$ stretching bond of amino acid, whereas the band observed at wavelength $1025 \mathrm{~cm}^{-1}$ can be attributed to C-O-C ether of polysaccharides [33,43]. The successful formation of $\mathrm{Zn}-\mathrm{O}$ was confirmed by the absorption band observed at $503 \mathrm{~cm}^{-1}$. Consistent with our data, the FT-IR analysis of green synthesized $\mathrm{ZnO}-\mathrm{NPs}$ showed the $\mathrm{Zn}-\mathrm{O}$ absorption band has been observed at wavelength $485 \mathrm{~cm}^{-1}$ [44], $442 \mathrm{~cm}^{-1}$ [45], in range 400 to $500 \mathrm{~cm}^{-1}$ [46], or at wavelength $782 \mathrm{~cm}^{-1}$ [47], $450 \mathrm{~cm}^{-1}$, and $600 \mathrm{~cm}^{-1}$ [48]. The data of FT-IR analysis exhibit the role of organic substances in A. platensis extract in the reduction, capping, and stabilizations of biosynthesized ZnO-NPs. Azizi et al. [49] suggested that the formation of ZnO-NPs was accomplished as a result of the interaction between oxygen in functional groups involved in cell extract of Sargassum muticum and zinc molecules in salt precursors.

\subsubsection{Transmission Electron Microscopy (TEM) and Energy-Dispersive Spectroscopy (EDX) Analysis}

Figure 4A,B showed the shape, size, as well as size distribution of ZnO-NPs fabricated by A. platensis. The TEM image exhibits a good distribution of spherical ZnO-NPs without any aggregation. Moreover, image analysis demonstrated that the size of fabricated $\mathrm{ZnO}-\mathrm{NPs}$ was in the range of 30.0 to $55.0 \mathrm{~nm}$. Recently, spherical ZnO-NPs were fabricated by Chlorella cell extract with the size range of 20.0-50.0 nm [40]. The efficacy of metabolites involved in algal cell extract to fabricate spherical ZnO-NPs was previously investigated [50].

The quantitative elemental structure of green synthesized ZnO-NPs was investigated by EDX analysis (Figure 4C). Data analysis revealed that the fabricated ZnO-NPs contain Zn, $\mathrm{O}, \mathrm{Na}, \mathrm{C}$, and $\mathrm{Al}$ with weight percentages $56.6,20.4,15.3,4.5$, and $3.2 \%$, respectively. The EDX result confirms the successful fabrication of $\mathrm{ZnO}$ through harnessing the metabolites involved in A. platensis filtrate; moreover, EDX analysis affirms that $\mathrm{Zn}$ and $\mathrm{O}$ occupied the major elements in the nanostructure. The presence of other peaks such as $\mathrm{C}, \mathrm{Na}$, and $\mathrm{Al}$ may be related to the breakdown of capping agents such as polysaccharides, proteins, amino acids, and sugars as a result of $X$-ray emissions [30]. A recent study confirmed the presence of $\mathrm{Zn}$ and $\mathrm{O}$ as a major component of $\mathrm{ZnO}-\mathrm{NPs}$ synthesized by cyanobacterium Nostoc sp. EA03 [50]. In addition, Djearamane et al. [51] reported that the main components of ZnO-NPs synthesized by Spirulina platensis were $\mathrm{Zn}$ and $\mathrm{O}$.

\subsubsection{X-ray Diffraction (XRD) Analysis}

The crystallographic structure of cyanobacterium-mediated biosynthesis of ZnO-NPs was assessed by XRD analysis. As depicted in Figure 5, the formed ZnO-NPs showed seven distinguished peaks at 2 theta degree $31.7^{\circ}, 34.5^{\circ}, 36.1^{\circ}, 47.4^{\circ}, 56.3^{\circ}, 63.1^{\circ}$, and $67.9^{\circ}$, which matched to (100), (002), (101), (102), (110), (103), and (112) planes, respectively. All outstanding diffraction peaks in XRD spectra are compatible with those recorded in the Joint Committee on Powder Diffraction Standards (JCPDS, card No. 89-7102), which confirm the crystallographic Wurtzite structure [16,50]. The average crystal size has been calculated from XRD analysis using the Debye-Scherrer equation, which in this study was approximately equal to $\approx 45 \mathrm{~nm}$. The data from $X R D$ are compatible with those obtained by TEM analysis. The presence of slight peaks in XRD spectra may be related to the crystallization of organic substances that coated the surface of ZnO-NPs [8]. 

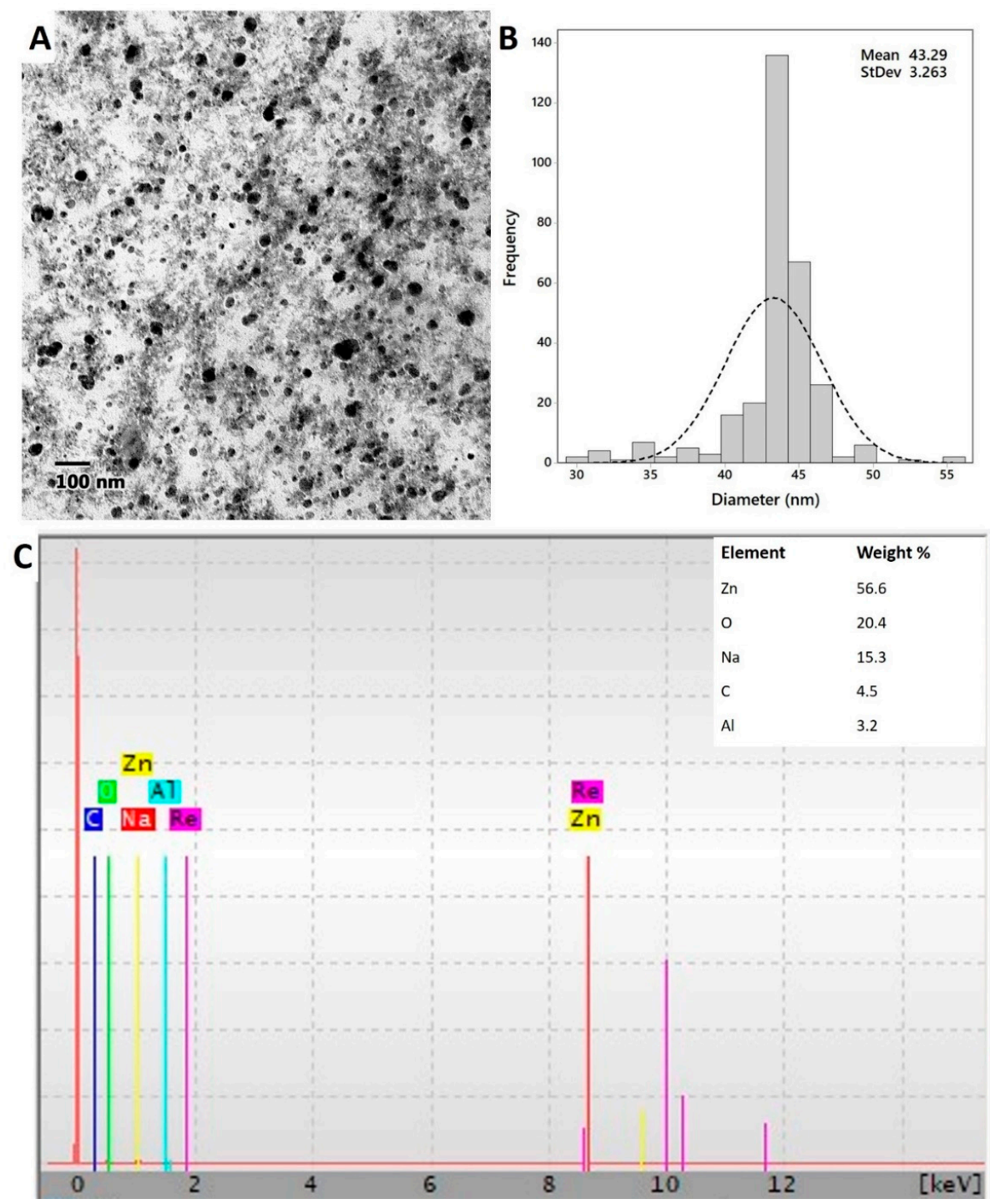

Figure 4. Transmission electron microscope (A), particle size distributions (B), and energy-dispersive spectroscopy (C) for ZnO-NPs synthesized by A. platensis.

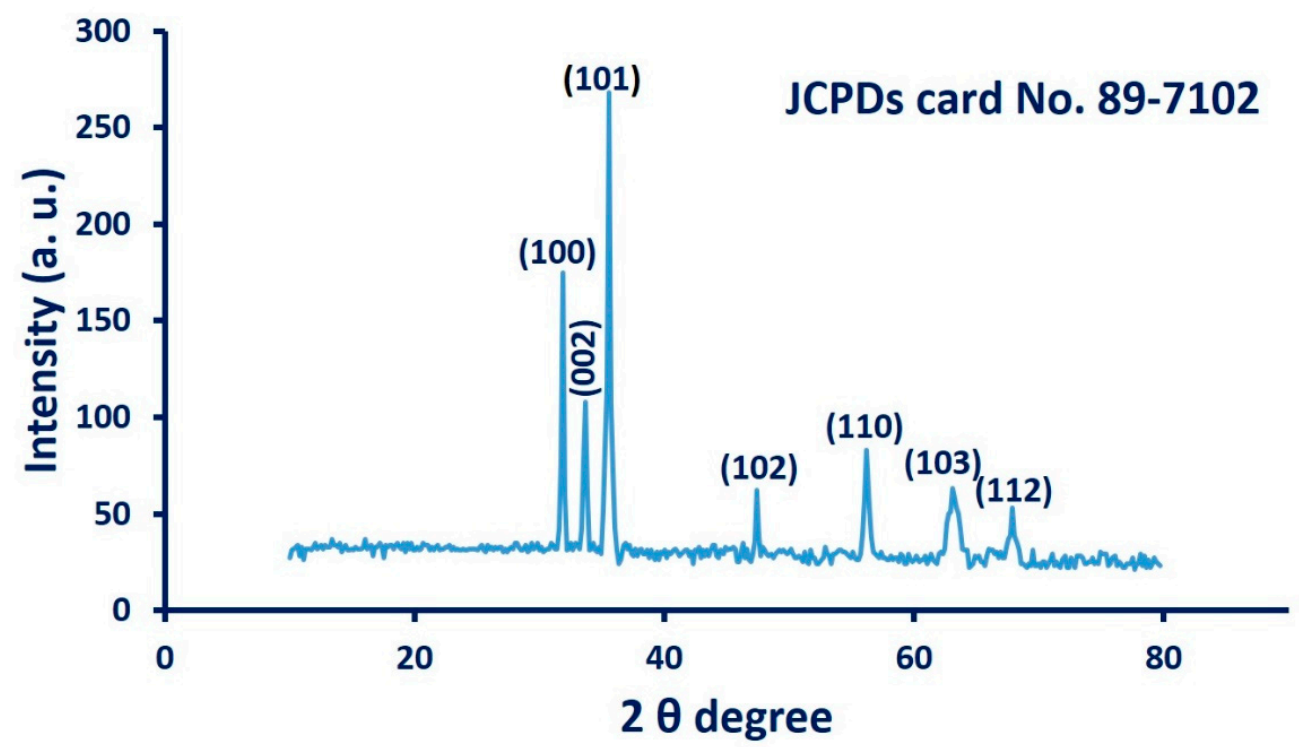

Figure 5. X-ray diffraction (XRD) pattern for ZnO-NPs synthesized by A. platensis. 


\subsubsection{X-ray Photoelectron Spectroscopy (XPS) Analysis}

Figure 6A shows the XPS survey spectra of the product. It confirms the composition of the substance by the presence of $\mathrm{C}, \mathrm{O}$, and $\mathrm{N}$ as $\mathrm{C} 1 \mathrm{~s}, \mathrm{O}(1 \mathrm{~s}, \mathrm{KL1})$, and $\mathrm{N} 1 \mathrm{~s}$. In addition, the survey analysis revealed the presence of $\mathrm{Na}$ as $\mathrm{Na}(2 s, 2 p, K L 1)$, while Zn was confirmed by Zn $(3 p, 3 d, 3 s, L M 1, L M 2, L M 5,2 p 1$, and 2p3).

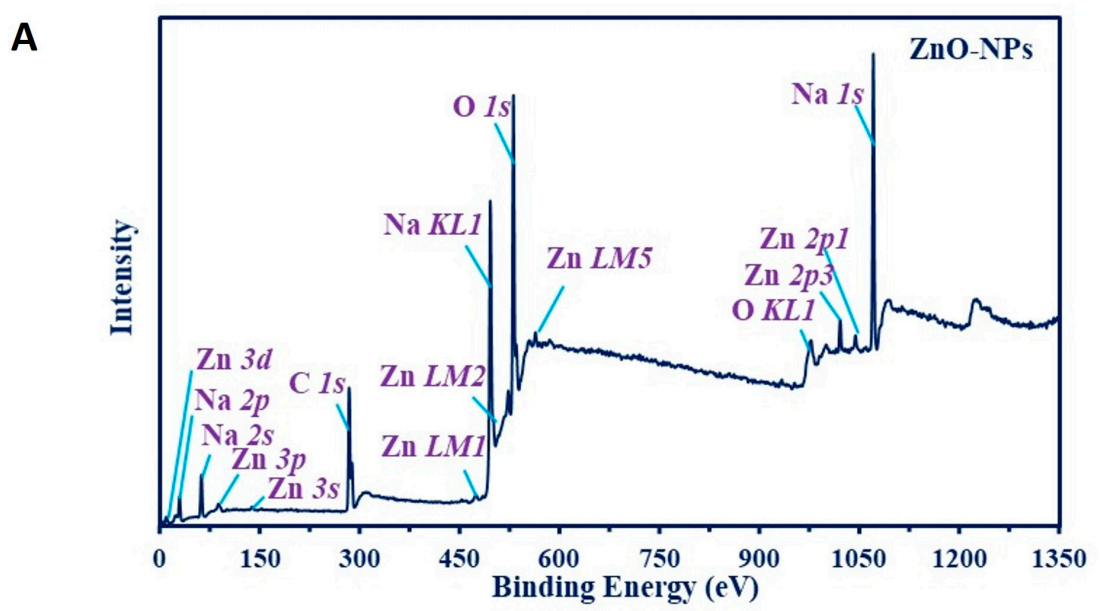

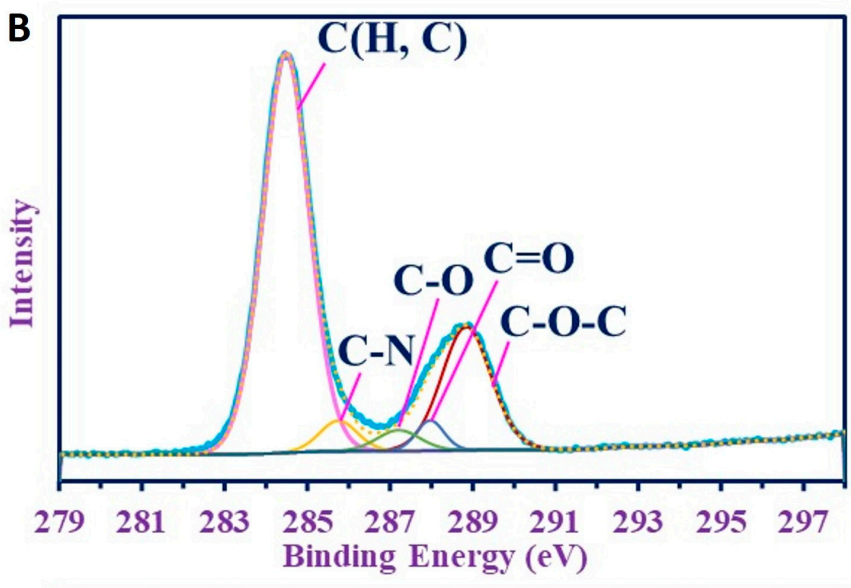

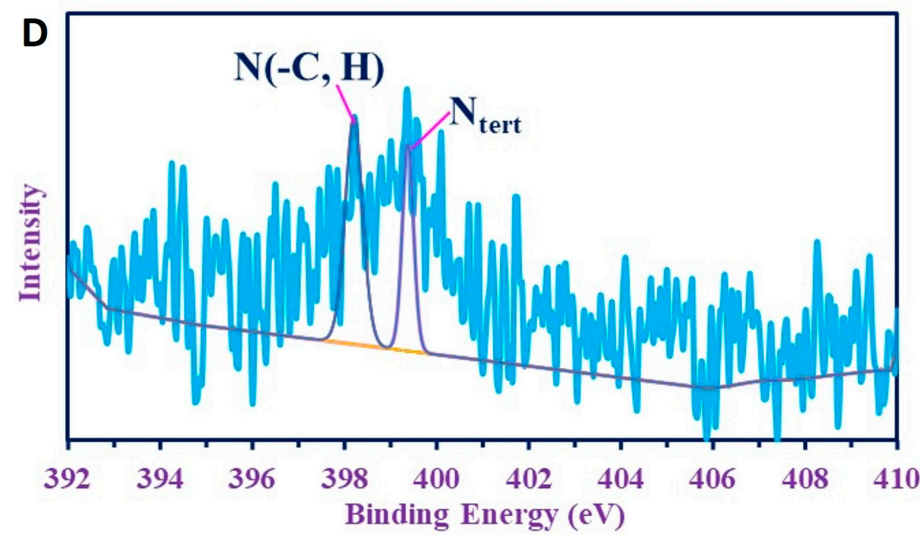

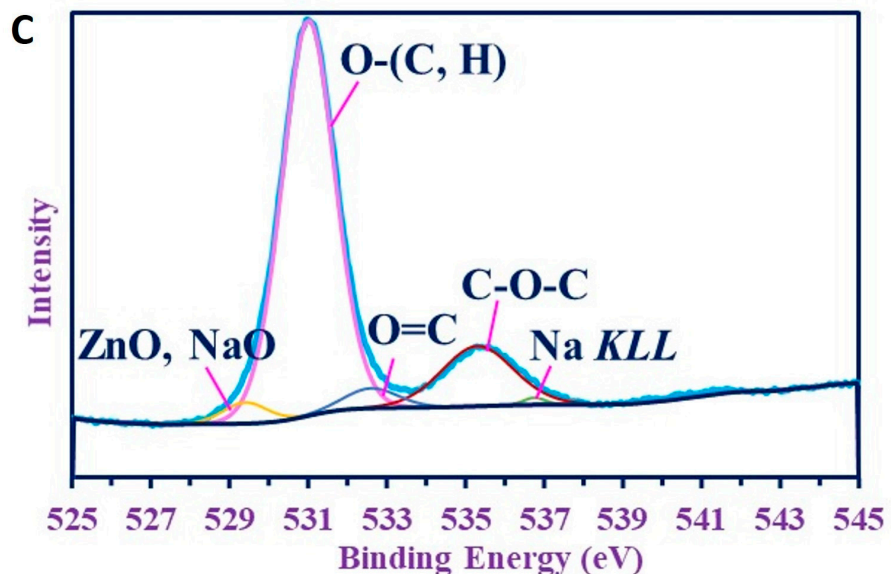

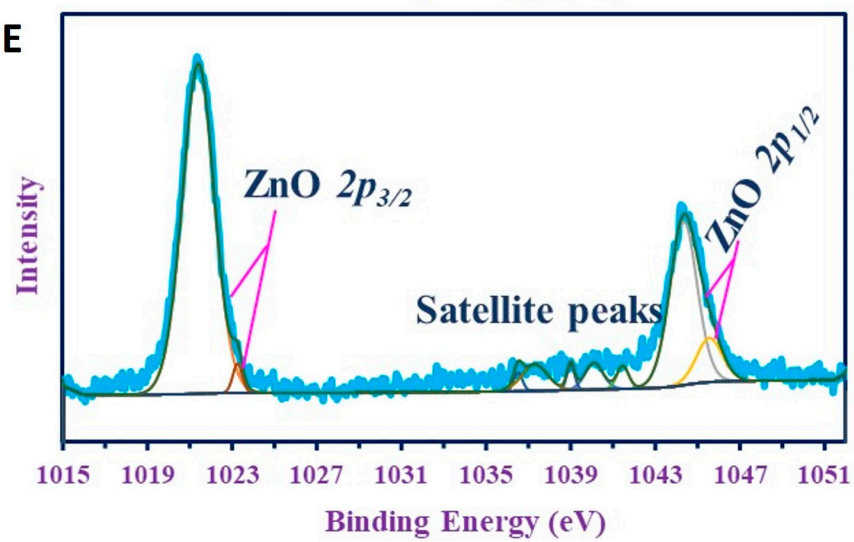

Figure 6. X-ray photoelectron spectroscopy analysis of ZnO-NPs synthesized by A. platensis. (A) Overview survey; (B-E) denotes $\mathrm{C} 1 s, \mathrm{O} 1 s, \mathrm{~N} 1 s$, and Zn $2 p$.

C 1s (Figure 6B) was split into five peaks at 284.48, 285.75, 287.9, 287.05, and $288.9 \mathrm{eV}$ for $\mathrm{C}(\mathrm{H}, \mathrm{C}), \mathrm{C}-\mathrm{N}, \mathrm{C}-\mathrm{O}, \mathrm{C}=\mathrm{O}$, and $\mathrm{C}-\mathrm{O}-\mathrm{C}$, respectively [52,53], verifying the hydrocarbon composition produced in the medium. $\mathrm{N} 1 \mathrm{~s}$ was deconvoluting into two peaks with low intensities at 398.2 and $399.37 \mathrm{eV}$ for $\mathrm{N}(\mathrm{C}, \mathrm{H})$ and $\mathrm{N}_{\text {tert }}$, respectively $[53,54]$.

$\mathrm{O} 1 \mathrm{~s}$ (Figure $6 \mathrm{C}$ ) has more peaks, verifying the structure of the materials; $\mathrm{ZnO}$ was 
overlapped with $\mathrm{NaO}$ at $529.4 \mathrm{eV}$, which confirms the presence of $\mathrm{Zn}$ as oxides. In addition, the excess amount of $\mathrm{Na}$ in the materials that appeared on the overall spectra is reflected in the $\mathrm{O} 1 \mathrm{~s}$ that have other peaks for Na KL1 at 536.75 (Figure 6D) [55], while the hydrocarbons peaks have appeared at 531, 532.2, and $535.3 \mathrm{eV}$ for $\mathrm{O}(\mathrm{C}, \mathrm{H}), \mathrm{O}=\mathrm{C}$, and $\mathrm{C}-\mathrm{O}-\mathrm{C}$, respectively $[33,52,55]$. These results were elucidated also by FT-IR with the broad bands of $\mathrm{NH}$ overlapped with $\mathrm{OH}, \mathrm{C}=\mathrm{O}, \mathrm{NH}$, and $\mathrm{C}-\mathrm{O}$ (see the FT-IR analysis). Zn $2 p$ (Figure 6E) have several peaks: two for $\mathrm{ZnO} 2 P_{3 / 2}$ at $1021.4 \mathrm{eV}$ and $1023.25 \mathrm{eV}$, another two peaks for $\mathrm{ZnO} 2 p_{1 / 2}$ at $1044.2 \mathrm{eV}$ and $1045.55 \mathrm{eV}$, while satellite peaks verifying the oxide species appeared at 1036.25, 1037.3, 1039, 1040.05, and $1041.65 \mathrm{eV}$. These spectra indicate the presence of $\mathrm{Zn}$ as $\mathrm{Zn}$ (II) oxide [56].

\subsection{Biological Activities of ZnO-NPs Synthesized by A. platensis}

\subsubsection{Antimicrobial Activity}

Figure 7 shows the antimicrobial activity of $\mathrm{ZnO}-\mathrm{NPs}$ synthesized by cyanobacterium A. platensis against pathogenic Gram-positive and Gram-negative bacteria as well as unicellular fungi. The obtained data indicated that the antimicrobial activities of NPs are increased with respect to concentration. This phenomenon was completely consistent with previous studies where the activity of $\mathrm{Ag}, \mathrm{ZnO}$ nanoparticles was dose- and shapedependent $[38,57]$. The cyanobacterium cell extract (as control) used to fabricate ZnO-NPs was tested as an antimicrobial agent against bacterial and unicellular fungal used and did not exhibit any activities. At stock colloidal solution (200 ppm), ZnO-NPs exhibit varied activities against Bacillus subtilis, Staphylococcus aureus, Pseudomonas aeruginosa, Escherichia coli, and Candida albicans with clear zones of $24.1 \pm 0.3,21.1 \pm 0.06,19.1 \pm 0.3,19.9 \pm 0.1$, and $21.6 \pm 0.6 \mathrm{~mm}$, respectively. As the NPs concentration decreased (50 ppm), the inhibition zone was decreased as well to $12.2 \pm 1.9,9.4 \pm 0.4,10.9 \pm 0.3,13.1 \pm 0.1$, and $13.2 \pm 0.3 \mathrm{~mm}$ for B. subtilis, S. aureus, P. aeruginosa, E. coli, and C. albicans, respectively. The published literature clarifies the antibacterial activity of green synthesized $\mathrm{ZnO}-\mathrm{NPs}$ against a wide range of pathogenic bacteria such as Streptococcus pyogenes, S. aureus, P. aeruginosa, E. coli, B. subtilis, Klebsiella aerogenes, Mycobacterium tuberculosis, and Proteus mirabilis [58]. Consistent with our study, spherical ZnO-NPs synthesized by the aqueous extract of Tabernaemontana divaricate with a size range of 20 to $50 \mathrm{~nm}$ have antibacterial activities against $S$. aureus, E. coli, and Salmonella paratyphi [59]. Recently, our study showed that the stock colloidal solution (2000 ppm) of spherical ZnO-NPs synthesized by Aspergillus terreus strain AF-1 with a size range of 10 to $45 \mathrm{~nm}$ have antibacterial activity against $B$. subtilis, $S$. aureus, E. coli, and P. aeruginosa with diameter inhibition zone ranging between $14.1 \pm 0.2$ and $20.2 \pm 0.2 \mathrm{~nm}[16]$.

The minimum inhibitory concentration (MIC) is defined as the lowest NPs concentration that inhibits microbial growth [60], and it should be detected for each organism. In this study, the MIC values were $50 \mathrm{ppm}$ for $S$. aureus $(9.4 \pm 0.4 \mathrm{~mm}), 25 \mathrm{ppm}$ for P. aeruginosa $(9.5 \pm 0.3 \mathrm{~mm})$, and $12.5 \mathrm{ppm}$ for B. subtilis, E. coli, and C. albicans recording inhibition zones $8.8 \pm 0.7,8.8 \pm 0.3$, and $9.6 \pm 0.4 \mathrm{~mm}$, respectively. The ZnO-NPs size and their concentrations have critical roles in antimicrobial activities. Several studies have also confirmed that the antibacterial activity of $\mathrm{ZnO}-\mathrm{NPs}$ is size and concentration-dependent [61]. The smaller NPs size means a large surface area; they penetrate the microbial cell easily through the cell membrane and then enhance antimicrobial efficacy with their high concentration [62]. This phenomenon encourages our finding that correlates between antimicrobial activity and smaller ZnO-NPs size, which in this study was 30.0 to $55.0 \mathrm{~nm}$.

The toxicity of $\mathrm{ZnO}-\mathrm{NPs}$ can be attributed to the generation of reactive oxygen species (ROS), the release of $\mathrm{Zn}\left(\mathrm{Zn}^{2+}\right)$ ions inside the microbes, and the change in cell wall permeability [63]. The generation of ROS is considered the major reason for nanotoxicity which involved the damage of cellular components (proteins, lipid, nucleic acid, phospholipid, amino acids) [61]. On the other hand, the release of zinc ions $\left(\mathrm{Zn}^{2+}\right)$ has a negative impact on the active transport system, enzymatic reactions, amino acid metabolism, binding to macromolecules, and hence all fundamental microbial functions are inhibited from con- 
tinuing [60]. The zinc oxides are amphoteric and can react with alkali and/or acids and release $\mathrm{Zn}^{2+}$ as shown in the following Equations (4)-(6) [60].

$$
\begin{gathered}
\mathrm{ZnO}+2 \mathrm{HCl} \stackrel{\text { Acidic medium }}{\longrightarrow} \mathrm{ZnCl}_{2}+\mathrm{H}_{2} \mathrm{O} \\
\mathrm{ZnO}+2 \mathrm{NaOH} \stackrel{\text { Alkaline medium }}{\longrightarrow} \mathrm{Na}_{2} \mathrm{ZnO}_{2}+\mathrm{H}_{2} \mathrm{O} \\
\mathrm{ZnCl}_{2} \stackrel{\text { Aquous medium }}{\longrightarrow} \mathrm{Zn}^{2+}+2 \mathrm{Cl}^{-}
\end{gathered}
$$

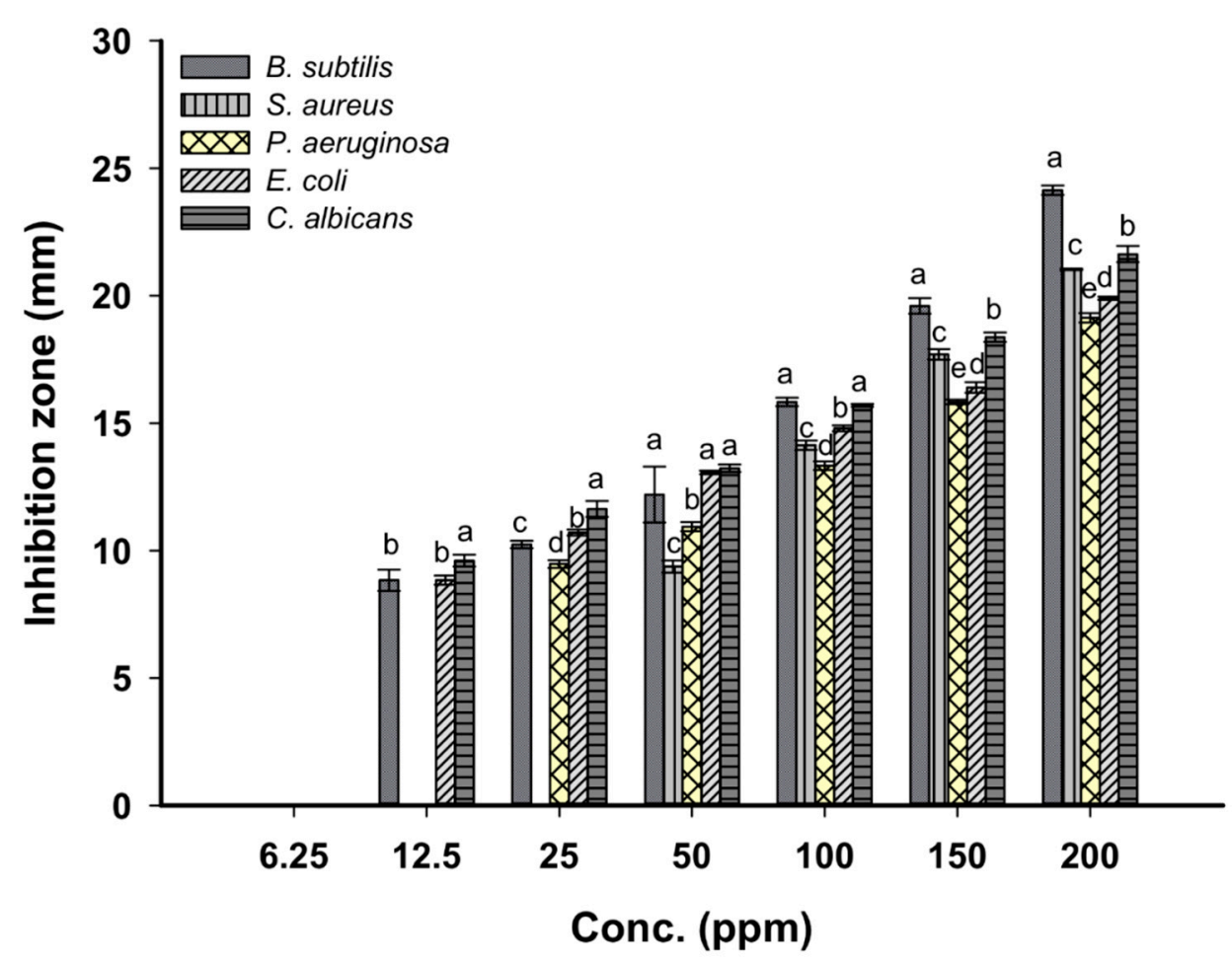

Figure 7. Antimicrobial activities of ZnO-NPs synthesized by A. platensis against Bacillus subtilis, Staphylococcus aureus, Pseudomonas aeruginosa, Escherichia coli, and Candida albicans. Data are statistically different at $p \leq 0.05$ by Tukey's test, $(n=3)$; error bars are means \pm SE. The different letters, a-e, are signified the significance. Bars with the same letter for each concentration did not differ significantly.

The accumulation of $\mathrm{ZnO}-\mathrm{NPs}$ in the microbial cell membrane is considered another mechanism for nanotoxicity, which correlated with the destruction of the proton motive force and hence changes the plasma membrane permeability. This change causes the rapid discharge of cellular components out of the microbial cell, and then cell viability was reduced $[7,61]$.

\subsubsection{In Vitro Cytotoxicity Assay}

Cancer is a life-threatening disease, and finding therapeutic drugs for the treatment of various types of cancer is a challenge. In this study, the cytotoxic efficacy of cyanobacteriummediated green synthesized ZnO-NPs was evaluated against two cell lines, WI 38 and Caco-2 by using the MTT assay method (Figure 8 ). The MTT method is a highly accurate and sensitive colorimetric method to investigate the cell viability after exposure to external substances [64]. MTT assay is dependent on the ability of succinate dehydrogenase mitochondrial enzyme to change the tetrazolium yellow dye to formazan crystals, which is directly proportional to cell viability and assayed as optical density [65]. The efficacy of $\mathrm{ZnO}-\mathrm{NPs}$ in the treatment of cancer cells is interesting, because it is more effective toward proliferative cells as compared to non-proliferative ones [66]. The toxicological efficacy 
of $\mathrm{ZnO}-\mathrm{NPs}$ has been investigated against different cell lines $[67,68]$. Some investigators reported that the $\mathrm{ZnO}-\mathrm{NPs}$ are toxic to cancerous cell lines only and do not have any cytotoxic effect against normal cells $[69,70]$. However, the recently little cytotoxic effect of $\mathrm{ZnO}-\mathrm{NPs}$ was shown toward normal cells as compared to cancerous cells. The ZnO-NPs fabricated by the methanolic extract of Sargassum muticum algal species showed toxic effect against cancerous cell lines MCF-7 and MDA-MB-231 and do not exhibit any activity against normal Vero cell; this could be attributed to an activated signal pathway through ligand/receptor interaction [71].

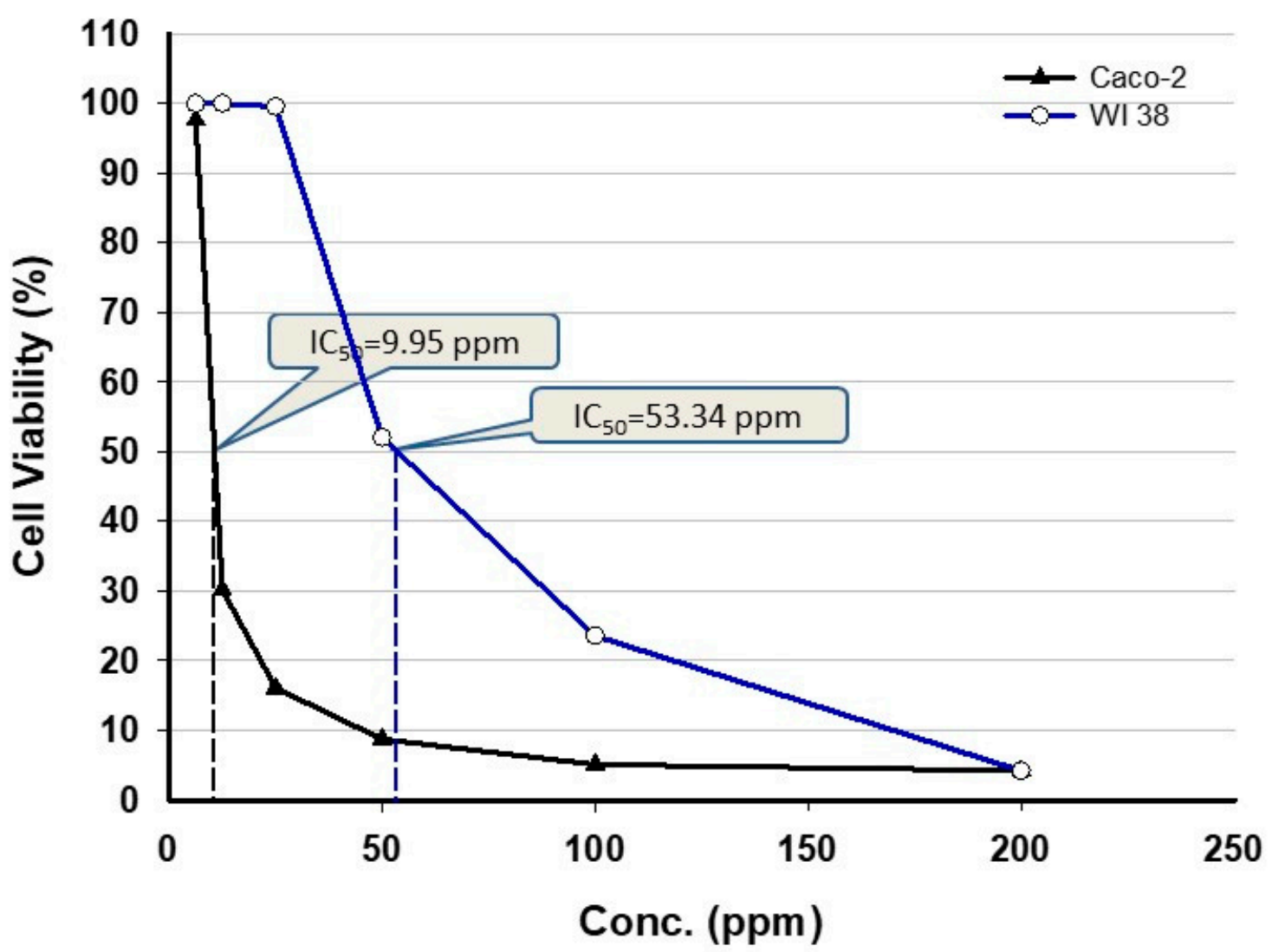

Figure 8. In vitro cytotoxic efficacy of ZnO-NPs synthesized by A. platensis against normal (WI 38) and cancerous (Caco-2) cell lines.

Data analysis revealed that the viability of treated cell lines was dose-dependent; as the NPs concentration increased, the viability was decreased. This finding is constant with Rajakumar et al. [72], who reported that apoptosis is correlated with high ZnO-NPs concentration. In this study, the cell viability of WI 83 (normal cell line) and Caco-2 (cancerous cell line) was measured after $48 \mathrm{~h}$ and exhibited that the $\mathrm{IC}_{50}$ were 53.34 and 9.95 ppm, respectively. According to these results, we can have concluded that the low $\mathrm{ZnO}-\mathrm{NPs}$ concentration was more effective on cancerous cells as compared to the normal cell line. Ngoepe et al. [73] and Agarwal et al. [74] showed that the cell viability due to $\mathrm{ZnO}-\mathrm{NPs}$ treatment was assessed after $48 \mathrm{~h}$. With our findings, previous studies proved the efficacy of NPs on cancerous cell viability such as MCF-7 as breast cancerous cell [75], MGC803 as gastric cancerous cell [75], Caco-2 as adenocarcinoma cell [76], and MG-63 as osteosarcoma cell [77]. Data recorded by Malaikozhundan et al. [78] were incompatible with our study, which showed that spherical ZnO-NPs with size 30-40 nm synthesized by seed extracts of Pongamia pinnata can reduce the cell viability of cancerous cell MCF-7 at a concentration higher than $50 \mathrm{ppm}$. On the other hand, $\mathrm{ZnO}-\mathrm{NPs}$ (with size range 20-50 nm) synthesized by the aqueous extract of algal species Gracilaria edulis have dose-dependent 
cytotoxic efficacy against $\mathrm{SiHa}$ (Human cervical cancer) cell line with an $\mathrm{IC}_{50}$ value of $35 \pm 0.03$ ppm [67].

Interestingly, ZnO-NPs are utilized widely in cancer therapy and can reduce the proliferation of cancer cells. Some of the published literature reported that ZnO-NPs are nontoxic and biocompatible [79], while others have reported both the in vivo and in vitro toxicity of the $\mathrm{ZnO}-\mathrm{NPs}$, particularly on mammalian cells [80]. According to data obtained in this study and others recently published, it can be clarified that the toxicity of ZnO-NPs is concentration-dependent. On the other hand, the treatment of leukemic T cells, cancerous cells, and inhibited pathogenic growth can be correlated with the toxicity of ZnO-NPs [81,82]. Other advantages correlated with ZnO-NPs include overcoming the drug-resistant problems within the pharmaceutical industry because of the non-selectivity of ZnO-NPs [83]. The biological activities of ZnO-NPs are correlated with their physicochemical properties as well as the dispersion characteristics of NPs. In some cases, the NPs agglomerate or aggregate when reacting with physiological fluids; therefore, the study of the dispersion efficacy of NPs is a critical factor to detect in vitro and in vivo cytotoxicity [84]. The addition of dispersant is an important factor to modify the physical and thermal properties of the NPs such as conductivity and viscosity [85]. The addition of dispersants was helpful in heat resistance in heat transfer applications and helped in foam formation during the heat and coal process [86].

\section{Conclusions}

The green synthesis of ZnO-NPs using microalga Arthrospira platensis has received prodigious interest because of their rapid growth, high biomass production, environmentally safe nature, and low-cost protocol. In this study, the microalgae A. platensis was isolated from the water sample and subjected to microscopic as well as molecular identification. The biosynthesized ZnO-NPs were characterized by UV-Visible spectroscopy, FT-IR, TEM, EDX, XRD, and XPS analyses. The obtained data showed the successful fabrication of spherical ZnO-NPs with a size range of 30.0 to $55.0 \mathrm{~nm}$ at a maximum wavelength of $370 \mathrm{~nm}$. The functional groups present in biomass filtrate have critical roles in the fabrication process as shown in FT-IR. Moreover, the crystallographic structure was confirmed by XRD. The XPS spectra indicated the presence of $\mathrm{Zn}$ as $\mathrm{Zn}$ (II) oxide. The biological activities including antimicrobial and in vitro cytotoxicity were also the main goals. Data showed that the activities of biosynthesized $\mathrm{ZnO}$-NPs were dose- and time-dependent. The biosynthesized ZnO-NPs exhibit varied activities against B. subtilis, S. aureus, P. aeruginosa, E. coli, and C. albicans with clear zones ranging between $19.1 \pm 0.3$ and $24.1 \pm 0.3 \mathrm{~mm}$. Moreover, the in vitro cytotoxic effect of ZnO-NPs against normal (WI 38) and cancer (Caco-2) cell lines was investigated. Data exhibit that the $\mathrm{IC}_{50}$ values were 53.34 and $9.95 \mathrm{ppm}$ for normal and cancer cell lines, respectively. The obtained data confirm the high efficacy of cyanobacterium A. platensis as a biocatalyst for the green synthesis of ZnO-NPs for integration into different biomedical applications.

Author Contributions: Conceptualization, E.F.E.-B., M.M.S.F., H.A.S. and A.F.; methodology, E.F.E.-B., M.M.S.F., H.A.S., A.S.A., E.A. and A.F.; software, E.F.E.-B., M.M.S.F., A.A.G., H.A.S. and A.F.; validation, E.F.E.-B., M.M.S.F., A.A.G., E.A., H.A.S. and A.F.; formal analysis, E.F.E.-B., M.M.S.F., H.A.S. and A.F.; investigation, E.F.E.-B., M.M.S.F., H.A.S., A.S.A. and A.F.; resources, E.F.E.-B., M.M.S.F., H.A.S., A.S.A., E.A., A.A.G. and A.F.; data curation, E.F.E.-B., M.M.S.F., H.A.S., A.S.A., E.A. and A.F.; writing-original draft preparation, E.F.E.-B., M.M.S.F., H.A.S. and A.F.; writing-review and editing, E.F.E.-B., M.M.S.F., H.A.S., A.S.A., E.A., A.A.G. and A.F.; visualization, E.F.E.-B., M.M.S.F., A.A.G., A.S.A., E.A. and A.F.; supervision, E.F.E.-B., M.M.S.F., A.A.G. and A.F. All authors have read and agreed to the published version of the manuscript.

Funding: This research received no external funding.

Data Availability Statement: The data presented in this study are available on request from the corresponding author. 
Acknowledgments: We thank Taif University Researchers Supporting Project number (TURSP2020/13), Taif University, Taif, Saudi Arabia.

Conflicts of Interest: The authors declare no conflict of interest.

\section{References}

1. Samak, D.H.; El-Sayed, Y.S.; Shaheen, H.M.; El-Far, A.H.; Abd El-Hack, M.E.; Noreldin, A.E.; El-Naggar, K.; Abdelnour, S.A.; Saied, E.M.; El-Seedi, H.R.; et al. Developmental Toxicity of Carbon Nanoparticles during Embryogenesis in Chicken. Environ. Sci. Pollut. Res. 2020, 27, 19058-19072. [CrossRef] [PubMed]

2. Aref, M.S.; Salem, S.S. Bio-callus synthesis of silver nanoparticles, characterization, and antibacterial activities via Cinnamomum camphora callus culture. Biocatal. Agric. Biotechnol. 2020, 27, 101689. [CrossRef]

3. Fouda, A.; Abdel-Maksoud, G.; Abdel-Rahman, M.A.; Salem, S.S.; Hassan, S.E.D.; El-Sadany, M.A.H. Eco-friendly approach utilizing green synthesized nanoparticles for paper conservation against microbes involved in biodeterioration of archaeological manuscript. Int. Biodeterior. Biodegrad. 2019, 142, 160-169. [CrossRef]

4. Alsharif, S.M.; Salem, S.S.; Abdel-Rahman, M.A.; Fouda, A.; Eid, A.M.; El-Din Hassan, S.; Awad, M.A.; Mohamed, A.A. Multifunctional properties of spherical silver nanoparticles fabricated by different microbial taxa. Heliyon 2020, 6, e03943. [CrossRef]

5. Shaheen, T.I.; Salem, S.S.; Zaghloul, S. A New Facile Strategy for Multifunctional Textiles Development through in Situ Deposition of $\mathrm{SiO}_{2} / \mathrm{TiO}_{2}$ Nanosols Hybrid. Ind. Eng. Chem. Res. 2019, 58, 20203-20212. [CrossRef]

6. Abdel-Azeem, A.; Nada, A.A.; O’Donovan, A.; Kumar Thakur, V.; Elkelish, A. Mycogenic Silver Nanoparticles from Endophytic Trichoderma Atroviride with Antimicrobial Activity. J. Renew. Mater. 2019, 7, 171-185. [CrossRef]

7. Salem, S.S.; Fouda, A. Green Synthesis of Metallic Nanoparticles and Their Prospective Biotechnological Applications: An Overview. Biol. Trace Elem. Res. 2021, 199, 344-370. [CrossRef]

8. Collenburg, L.; Beyersdorf, N.; Wiese, T.; Arenz, C.; Saied, E.M.; Becker-Flegler, K.A.; Schneider-Schaulies, S.; Avota, E. The Activity of the Neutral Sphingomyelinase Is Important in T Cell Recruitment and Directional Migration. Front. Immunol. 2017, 8, 1007. [CrossRef]

9. Mohamed, A.A.; Abu-Elghait, M.; Ahmed, N.E.; Salem, S.S. Eco-friendly Mycogenic Synthesis of ZnO and CuO Nanoparticles for In Vitro Antibacterial, Antibiofilm, and Antifungal Applications. Biol. Trace Elem. Res. 2020. [CrossRef] [PubMed]

10. Salem, S.S.; EL-Belely, E.F.; Niedbała, G.; Alnoman, M.M.; Hassan, S.E.-D.; Eid, A.M.; Shaheen, T.I.; Elkelish, A.; Fouda, A. Bactericidal and In-Vitro Cytotoxic Efficacy of Silver Nanoparticles (Ag-NPs) Fabricated by Endophytic Actinomycetes and Their Use as Coating for the Textile Fabrics. Nanomaterials 2020, 10, 2082. [CrossRef] [PubMed]

11. Mohd Yusof, H.; Mohamad, R.; Zaidan, U.H.; Abdul Rahman, N.A. Microbial synthesis of zinc oxide nanoparticles and their potential application as an antimicrobial agent and a feed supplement in animal industry: A review. J. Anim. Sci. Biotechnol. 2019, 10, 57. [CrossRef] [PubMed]

12. Soliman, M.; Qari, S.H.; Abu-Elsaoud, A.; El-Esawi, M.; Alhaithloul, H.; Elkelish, A. Rapid Green Synthesis of Silver Nanoparticles from Blue Gum Augment Growth and Performance of Maize, Fenugreek, and Onion by Modulating Plants Cellular Antioxidant Machinery and Genes Expression. Acta Physiol. Plant. 2020, 42, 148. [CrossRef]

13. Ruszkiewicz, J.A.; Pinkas, A.; Ferrer, B.; Peres, T.V.; Tsatsakis, A.; Aschner, M. Neurotoxic effect of active ingredients in sunscreen products, a contemporary review. Toxicol. Rep. 2017, 4, 245-259. [CrossRef] [PubMed]

14. Sahoo, S.; Maiti, M.; Ganguly, A.; Jacob George, J.; Bhowmick, A.K. Effect of zinc oxide nanoparticles as cure activator on the properties of natural rubber and nitrile rubber. J. Appl. Polym. Sci. 2007, 105, 2407-2415. [CrossRef]

15. Newman, M.D.; Stotland, M.; Ellis, J.I. The safety of nanosized particles in titanium dioxide- and zinc oxide-based sunscreens. J. Am. Acad. Dermatol. 2009, 61, 685-692. [CrossRef] [PubMed]

16. Fouda, A.; El-Din Hassan, S.; Salem, S.S.; Shaheen, T.I. In-Vitro cytotoxicity, antibacterial, and UV protection properties of the biosynthesized Zinc oxide nanoparticles for medical textile applications. Microb. Pathog. 2018, 125, 252-261. [CrossRef] [PubMed]

17. Kołodziejczak-Radzimska, A.; Jesionowski, T. Zinc oxide-From synthesis to application: A review. Materials 2014, 7, $2833-2881$. [CrossRef]

18. Mirzaei, H.; Darroudi, M. Zinc oxide nanoparticles: Biological synthesis and biomedical applications. Ceram. Int. 2017, 43, 907-914. [CrossRef]

19. Abedini, M.; Shariatmadari, F.; Karimi Torshizi, M.A.; Ahmadi, H. Effects of zinc oxide nanoparticles on the egg quality, immune response, zinc retention, and blood parameters of laying hens in the late phase of production. J. Anim. Physiol. Anim. Nutr. 2018, 102, 736-745. [CrossRef]

20. Food and Drug Administration (FDA). Select Committee on GRAS Substances (SCOGS) Opinion: Tannic acid (hydrolyzable gallotannins). In GRAS Substances (SCOGS) Database; Food and Drug Administration (FDA): Rockville, MD, USA, 2015.

21. Rastogi, R.P.; Sinha, R.P. Biotechnological and industrial significance of cyanobacterial secondary metabolites. Biotechnol. Adv. 2009, 27, 521-539. [CrossRef]

22. Husain, S.; Afreen, S.; Yasin, D.; Afzal, B.; Fatma, T. Cyanobacteria as a bioreactor for synthesis of silver nanoparticles-an effect of different reaction conditions on the size of nanoparticles and their dye decolorization ability. J. Microbiol. Methods 2019, 162, 77-82. [CrossRef] [PubMed] 
23. Brayner, R.; Barberousse, H.; Hemadi, M.; Djedjat, C.; Yéprémian, C.; Coradin, T.; Livage, J.; Fiévet, F.; Couté, A. Cyanobacteria as bioreactors for the synthesis of $\mathrm{Au}, \mathrm{Ag}$, Pd, and Pt nanoparticles via an enzyme-mediated route. J. Nanosci. Nanotechnol. 2007, 7, 2696-2708. [CrossRef] [PubMed]

24. Cepoi, L.; Rudi, L.; Chiriac, T.; Valuta, A.; Zinicovscaia, I.; Duca, G.; Kirkesali, E.; Frontasyeva, M.; Culicov, O.; Pavlov, S.; et al. Biochemical changes in cyanobacteria during the synthesis of silver nanoparticles. Can. J. Microbiol. 2015, 61, 13-21. [CrossRef] [PubMed]

25. Srivastava, A.K.; Rai, A.N.; Neilan, B.A. Stress Biology of Cyanobacteria: Molecular Mechanisms to Cellular Responses; CRC Press: Boca Raton, FL, USA, 2013.

26. Kaliamurthi, S.; Selvaraj, G.; Çakmak, Z.E.; Çakmak, T. Production and characterization of spherical thermostable silver nanoparticles from Spirulina platensis (Cyanophyceae). Phycologia 2016, 55, 568-576. [CrossRef]

27. Edlund, M.B. Freshwater Algae of North America. Ecology and Classification. J. Phycol. 2003, 39, 624-625. [CrossRef]

28. Miller, D.; Bryant, J.; Madsen, E.; Ghiorse, W. Evaluation and optimization of DNA extraction and purification procedures for soil and sediment samples. Appl. Environ. Microbiol. 1999, 65, 4715-4724. [CrossRef]

29. Fouda, A.; Eid, A.M.; Elsaied, A.; El-Belely, E.F.; Barghoth, M.G.; Azab, E.; Gobouri, A.A.; Hassan, S.E.-D. Plant Growth-Promoting Endophytic Bacterial Community Inhabiting the Leaves of Pulicaria incisa (Lam.) DC Inherent to Arid Regions. Plants 2021, 10, 76. [CrossRef]

30. Fouda, A.; Salem, S.S.; Wassel, A.R.; Hamza, M.F.; Shaheen, T.I. Optimization of green biosynthesized visible light active $\mathrm{CuO} / \mathrm{ZnO}$ nano-photocatalysts for the degradation of organic methylene blue dye. Heliyon 2020, 6, e04896. [CrossRef]

31. Shaheen, T.I.; Fouda, A. Green approach for one-pot synthesis of silver nanorod using cellulose nanocrystal and their cytotoxicity and antibacterial assessment. Int. J. Biol. Macromol. 2018, 106, 784-792. [CrossRef]

32. Fouda, A.; Hassan, S.E.-D.; Saied, E.; Azab, M.S. An eco-friendly approach to textile and tannery wastewater treatment using maghemite nanoparticles $\left(\gamma-\mathrm{Fe}_{2} \mathrm{O}_{3}-\mathrm{NPs}\right)$ fabricated by Penicillium expansum strain (K-w). J. Environ. Chem. Eng. 2020, 104693. [CrossRef]

33. Hamza, M.F.; Wei, Y.; Benettayeb, A.; Wang, X.; Guibal, E. Efficient removal of uranium, cadmium and mercury from aqueous solutions using grafted hydrazide-micro-magnetite chitosan derivative. J. Mater. Sci. 2019, 55, 1-20. [CrossRef]

34. Hassan, S.E.D.; Fouda, A.; Radwan, A.A.; Salem, S.S.; Barghoth, M.G.; Awad, M.A.; Abdo, A.M.; El-Gamal, M.S. Endophytic actinomycetes Streptomyces spp. mediated biosynthesis of copper oxide nanoparticles as a promising tool for biotechnological applications. J. Biol. Inorg. Chem. 2019, 24, 377-393. [CrossRef] [PubMed]

35. Hassan, S.E.L.D.; Salem, S.S.; Fouda, A.; Awad, M.A.; El-Gamal, M.S.; Abdo, A.M. New approach for antimicrobial activity and bio-control of various pathogens by biosynthesized copper nanoparticles using endophytic actinomycetes. J. Radiat. Res. Appl. Sci. 2018, 11, 262-270. [CrossRef]

36. Philip, S.; Kundu, G.C. Osteopontin induces nuclear factor $\kappa B$-mediated promatrix metalloproteinase-2 activation through $\mathrm{I} \mathrm{K} \mathrm{B} \alpha / \mathrm{IKK}$ signaling pathways, and curcumin (diferulolylmethane) down-regulates these pathways. J. Biol. Chem. 2003, 278, 14487-14497. [CrossRef]

37. Singh, G.; Babele, P.K.; Kumar, A.; Srivastava, A.; Sinha, R.P.; Tyagi, M.B. Synthesis of ZnO nanoparticles using the cell extract of the cyanobacterium, Anabaena strain L31 and its conjugation with UV-B absorbing compound shinorine. J. Photochem. Photobiol. B Biol. 2014, 138, 55-62. [CrossRef] [PubMed]

38. Mohamed, A.A.; Fouda, A.; Abdel-Rahman, M.A.; Hassan, S.E.D.; El-Gamal, M.S.; Salem, S.S.; Shaheen, T.I. Fungal strain impacts the shape, bioactivity and multifunctional properties of green synthesized zinc oxide nanoparticles. Biocatal. Agric. Biotechnol. 2019, 19, 101103. [CrossRef]

39. Vennila, S.; Jesurani, S.S. Eco-friendly green synthesis and characterization of stable ZnO Nanoparticle using small Gooseberry fruits extracts. Int. J. Chemtech Res. 2017, 10, 271-275.

40. Khalafi, T.; Buazar, F.; Ghanemi, K. Phycosynthesis and Enhanced Photocatalytic Activity of Zinc Oxide Nanoparticles Toward Organosulfur Pollutants. Sci. Rep. 2019, 9, 6866. [CrossRef]

41. Duygu, D.Y.; Udoh, A.U.; Ozer, T.B.; Akbulut, A.; Erkaya, I.A.; Yildiz, K.; Guler, D. Fourier transform infrared (FTIR) spectroscopy for identification of Chlorella vulgaris Beijerinck 1890 and Scenedesmus obliquus (Turpin) Kützing 1833. Afr. J. Biotechnol. 2012, 11, 3817-3824.

42. Jabs, A.; Determination of Secondary Structure in Proteins by Fourier Transform Infrared Spectroscopy (FTIR). Jena Library of Biological Macromolecules. 2005. Available online: http://www.imb-jena.de/ImgLibDoc/ftir/IMAGEpFTIR.html (accessed on 30 December 2020).

43. Hamza, M.F.; Roux, J.-C.; Guibal, E. Uranium and europium sorption on amidoxime-functionalized magnetic chitosan microparticles. Chem. Eng. J. 2018, 344, 124-137. [CrossRef]

44. Buazar, F.; Bavi, M.; Kroushawi, F.; Halvani, M.; Khaledi-Nasab, A.; Hossieni, S.A. Potato extract as reducing agent and stabiliser in a facile green one-step synthesis of ZnO nanoparticles. J. Exp. Nanosci. 2016, 11, 175-184. [CrossRef]

45. Nagarajan, S.; Arumugam Kuppusamy, K. Extracellular synthesis of zinc oxide nanoparticle using seaweeds of gulf of Mannar, India. J. Nanobiotechnol. 2013, 11, 39. [CrossRef] [PubMed]

46. Zhang, G.; Shen, X.; Yang, Y. Facile Synthesis of Monodisperse Porous ZnO Spheres by a Soluble Starch-Assisted Method and Their Photocatalytic Activity. J. Phys. Chem. C 2011, 115, 7145-7152. [CrossRef] 
47. Singh, J.; Kaur, S.; Kaur, G.; Basu, S.; Rawat, M. Biogenic ZnO nanoparticles: A study of blueshift of optical band gap and photocatalytic degradation of reactive yellow 186 dye under direct sunlight. Green Process. Synth. 2019, 8, 272-280. [CrossRef]

48. Fakhari, S.; Jamzad, M.; Kabiri Fard, H. Green synthesis of zinc oxide nanoparticles: A comparison. Green Chem. Lett. Rev. 2019, 12, 19-24. [CrossRef]

49. Azizi, S.; Namvar, F.; Mahdavi, M.; Ahmad, M.B.; Mohamad, R. Biosynthesis of Silver Nanoparticles Using Brown Marine Macroalga, Sargassum Muticum Aqueous Extract. Materials 2013, 6, 5942-5950. [CrossRef]

50. Ebadi, M.; Zolfaghari, M.R.; Aghaei, S.S.; Zargar, M.; Shafiei, M.; Zahiri, H.S.; Noghabi, K.A. A bio-inspired strategy for the synthesis of zinc oxide nanoparticles (ZnO NPs) using the cell extract of cyanobacterium Nostoc sp. EA03: From biological function to toxicity evaluation. RSC Adv. 2019, 9, 23508-23525. [CrossRef]

51. Djearamane, S.; Lim, Y.M.; Wong, L.S.; Lee, P.F. Cytotoxic effects of zinc oxide nanoparticles on cyanobacterium Spirulina (Arthrospira) platensis. PeerJ 2018, 6, e4682. [CrossRef]

52. Hamza, M.F.; Gamal, A.; Hussein, G.; Nagar, M.S.; Abdel-Rahman, A.A.-H.; Wei, Y.; Guibal, E. Uranium(VI) and zirconium(IV) sorption on magnetic chitosan derivatives-Effect of different functional groups on separation properties. J. Chem. Technol. Biotechnol. 2019, 94, 3866-3882. [CrossRef]

53. Hamza, M.F.; Mubark, A.E.; Wei, Y.; Vincent, T.; Guibal, E. Quaternization of Composite Algal/PEI Beads for Enhanced Uranium Sorption-Application to Ore Acidic Leachate. Gels 2020, 6, 12. [CrossRef]

54. Hamza, M.F.; Lu, S.; Salih, K.A.M.; Mira, H.; Dhmees, A.S.; Fujita, T.; Wei, Y.; Vincent, T.; Guibal, E. As(V) sorption from aqueous solutions using quaternized algal/polyethyleneimine composite beads. Sci. Total Environ. 2020, 719, 137396. [CrossRef] [PubMed]

55. Wei, Y.; Salih, K.A.; Lu, S.; Hamza, M.F.; Fujita, T.; Vincent, T.; Guibal, E. Amidoxime Functionalization of Algal/Polyethyleneimine Beads for the Sorption of Sr (II) from Aqueous Solutions. Molecules 2019, 24, 3893. [CrossRef] [PubMed]

56. Alamdari, S.; Sasani Ghamsari, M.; Lee, C.; Han, W.; Park, H.-H.; Tafreshi, M.J.; Afarideh, H.; Ara, M.H.M. Preparation and Characterization of Zinc Oxide Nanoparticles Using Leaf Extract of Sambucus ebulus. Appl. Sci. 2020, 10, 3620. [CrossRef]

57. Fouda, A.; Hassan, S.E.-D.; Abdo, A.M.; El-Gamal, M.S. Antimicrobial, Antioxidant and Larvicidal activities of spherical silver nanoparticles synthesized by endophytic Streptomyces spp. Biol. Trace Elem. Res. 2020, 195, 707-724. [CrossRef] [PubMed]

58. Happy, A.; Soumya, M.; Venkat Kumar, S.; Rajeshkumar, S. Mechanistic study on antibacterial action of zinc oxide nanoparticles synthesized using green route. Chem. Biol. Interact. 2018, 286, 60-70. [CrossRef] [PubMed]

59. Raja, A.; Ashokkumar, S.; Pavithra Marthandam, R.; Jayachandiran, J.; Khatiwada, C.P.; Kaviyarasu, K.; Ganapathi Raman, R.; Swaminathan, M. Eco-friendly preparation of zinc oxide nanoparticles using Tabernaemontana divaricata and its photocatalytic and antimicrobial activity. J. Photochem. Photobiol. Biol. 2018, 181, 53-58. [CrossRef]

60. Siddiqi, K.S.; ur Rahman, A.; Husen, A. Properties of Zinc Oxide Nanoparticles and Their Activity Against Microbes. Nanoscale Res. Lett. 2018, 13, 141. [CrossRef]

61. Sirelkhatim, A.; Mahmud, S.; Seeni, A.; Kaus, N.H.M.; Ann, L.C.; Bakhori, S.K.M.; Hasan, H.; Mohamad, D. Review on zinc oxide nanoparticles: Antibacterial activity and toxicity mechanism. Nanomicro Lett. 2015, 7, 219-242. [CrossRef]

62. Padmavathy, N.; Vijayaraghavan, R. Enhanced bioactivity of ZnO nanoparticles-An antimicrobial study. Sci. Technol. Adv. Mater. 2008, 9, 035004. [CrossRef]

63. Taghizadeh, S.-M.; Lal, N.; Ebrahiminezhad, A.; Moeini, F.; Seifan, M.; Ghasemi, Y.; Berenjian, A. Green and Economic Fabrication of Zinc Oxide (ZnO) Nanorods as a Broadband UV Blocker and Antimicrobial Agent. Nanomaterials 2020, 10, 530. [CrossRef]

64. Rai, Y.; Pathak, R.; Kumari, N.; Sah, D.K.; Pandey, S.; Kalra, N.; Soni, R.; Dwarakanath, B.S.; Bhatt, A.N. Mitochondrial biogenesis and metabolic hyperactivation limits the application of MTT assay in the estimation of radiation induced growth inhibition. Sci. Rep. 2018, 8, 1531. [CrossRef] [PubMed]

65. Hussain, R.F.; Nouri, A.M.E.; Oliver, R.T.D. A new approach for measurement of cytotoxicity using colorimetric assay. J. Immunol. Methods 1993, 160, 89-96. [CrossRef]

66. Valdiglesias, V.; Costa, C.; Kiliç, G.; Costa, S.; Pásaro, E.; Laffon, B.; Teixeira, J.P. Neuronal cytotoxicity and genotoxicity induced by zinc oxide nanoparticles. Environ. Int. 2013, 55, 92-100. [CrossRef] [PubMed]

67. Gowdhami, B.; Jaabir, M.; Archunan, G.; Suganthy, N. Anticancer potential of zinc oxide nanoparticles against cervical carcinoma cells synthesized via biogenic route using aqueous extract of Gracilaria edulis. Mater. Sci. Eng. C Mater. Biol. Appl. 2019, 103, 109840.

68. Sanaeimehr, Z.; Javadi, I.; Namvar, F. Antiangiogenic and antiapoptotic effects of green-synthesized zinc oxide nanoparticles using Sargassum muticum algae extraction. Cancer Nanotechnol. 2018, 9, 1-6. [CrossRef] [PubMed]

69. Akhtar, M.J.; Ahamed, M.; Kumar, S.; Khan, M.M.; Ahmad, J.; Alrokayan, S.A. Zinc oxide nanoparticles selectively induce apoptosis in human cancer cells through reactive oxygen species. Int. J. Nanomed. 2012, 7, 845-857.

70. Taccola, L.; Raffa, V.; Riggio, C.; Vittorio, O.; Iorio, M.C.; Vanacore, R.; Pietrabissa, A.; Cuschieri, A. Zinc oxide nanoparticles as selective killers of proliferating cells. Int. J. Nanomed. 2011, 6, 1129-1140.

71. Namvar, F.; Mohamad, R.; Baharara, J.; Zafar-Balanejad, S.; Fargahi, F.; Rahman, H.S. Antioxidant, Antiproliferative, and Antiangiogenesis Effects of Polyphenol-Rich Seaweed (Sargassum muticum). Biomed Res. Int. 2013, 2013, 604787. [CrossRef]

72. Rajakumar, G.; Thiruvengadam, M.; Mydhili, G.; Gomathi, T.; Chung, I.-M. Green approach for synthesis of zinc oxide nanoparticles from Andrographis paniculata leaf extract and evaluation of their antioxidant, anti-diabetic, and anti-inflammatory activities. Bioprocess Biosyst. Eng. 2018, 41, 21-30. [CrossRef] 
73. Ngoepe, N.M.; Mbita, Z.; Mathipa, M.; Mketo, N.; Ntsendwana, B.; Hintsho-Mbita, N.C. Biogenic synthesis of ZnO nanoparticles using Monsonia burkeana for use in photocatalytic, antibacterial and anticancer applications. Ceram. Int. 2018, 44, 16999-17006. [CrossRef]

74. Agarwal, H.; Venkat Kumar, S.; Rajeshkumar, S. A review on green synthesis of zinc oxide nanoparticles-An eco-friendly approach. Resour. Effic. Technol. 2017, 3, 406-413. [CrossRef]

75. Boroumand Moghaddam, A.; Moniri, M.; Azizi, S.; Abdul Rahim, R.; Bin Ariff, A.; Navaderi, M.; Mohamad, R. Eco-Friendly Formulated Zinc Oxide Nanoparticles: Induction of Cell Cycle Arrest and Apoptosis in the MCF-7 Cancer Cell Line. Genes 2017, 8, 281. [CrossRef] [PubMed]

76. Eid, A.M.; Fouda, A.; Niedbała, G.; Hassan, S.E.D.; Salem, S.S.; Abdo, A.M.; Hetta, H.F.; Shaheen, T.I. Endophytic Streptomyces laurentii mediated green synthesis of Ag-NPs with antibacterial and anticancer properties for developing functional textile fabric properties. Antibiotics 2020, 9, 641. [CrossRef] [PubMed]

77. Sisubalan, N.; Ramkumar, V.S.; Pugazhendhi, A.; Karthikeyan, C.; Indira, K.; Gopinath, K.; Hameed, A.S.H.; Basha, M.H.G. ROS-mediated cytotoxic activity of $\mathrm{ZnO}$ and $\mathrm{CeO}_{2}$ nanoparticles synthesized using the Rubia cordifolia L. leaf extract on MG-63 human osteosarcoma cell lines. Environ. Sci. Pollut. Res. 2018, 25, 10482-10492. [CrossRef] [PubMed]

78. Malaikozhundan, B.; Vaseeharan, B.; Vijayakumar, S.; Pandiselvi, K.; Kalanjiam, M.A.; Murugan, K.; Benelli, G. Biological therapeutics of Pongamia pinnata coated zinc oxide nanoparticles against clinically important pathogenic bacteria, fungi and MCF-7 breast cancer cells. Microb. Pathog. 2017, 104, 268-277. [CrossRef]

79. Zvyagin, A.V.; Zhao, X.; Gierden, A.; Sanchez, W.; Ross, J.; Roberts, M.S. Imaging of zinc oxide nanoparticle penetration in human skin in vitro and in vivo. J. Biomed. Opt. 2008, 13, 064031. [CrossRef]

80. Vandebriel, R.J.; De Jong, W.H. A review of mammalian toxicity of ZnO nanoparticles. Nanotechnol. Sci. Appl. 2012, 5, 61-71. [CrossRef]

81. Premanathan, M.; Karthikeyan, K.; Jeyasubramanian, K.; Manivannan, G. Selective toxicity of ZnO nanoparticles toward Grampositive bacteria and cancer cells by apoptosis through lipid peroxidation. Nanomed. Nanotechnol. Biol. Med. 2011, 7, 184-192. [CrossRef]

82. Guo, D.; Wu, C.; Jiang, H.; Li, Q.; Wang, X.; Chen, B. Synergistic cytotoxic effect of different sized ZnO nanoparticles and daunorubicin against leukemia cancer cells under UV irradiation. J. Photochem. Photobiol. B Biol. 2008, 93, 119-126. [CrossRef]

83. Liu, J.; Ma, X.; Jin, S.; Xue, X.; Zhang, C.; Wei, T.; Guo, W.; Liang, X.-J. Zinc oxide nanoparticles as adjuvant to facilitate doxorubicin intracellular accumulation and visualize pH-responsive release for overcoming drug resistance. Mol. Pharm. 2016, 13, 1723-1730. [CrossRef]

84. Jo, M.-R.; Chung, H.-E.; Kim, H.-J.; Bae, S.-H.; Go, M.-R.; Yu, J.; Choi, S.-J. Effects of zinc oxide nanoparticle dispersants on cytotoxicity and cellular uptake. Mol. Cell. Toxicol. 2016, 12, 281-288. [CrossRef]

85. Chakraborty, S.; Sarkar, I.; Behera, D.K.; Pal, S.K.; Chakraborty, S. Experimental investigation on the effect of dispersant addition on thermal and rheological characteristics of $\mathrm{TiO}_{2}$ nanofluid. Powder Technol. 2017, 307, 10-24. [CrossRef]

86. Pavithra, K.S.; Fasiulla; Puttaiahgowda, Y.; Prasannakumar, S. Synthesis, characterisation and thermal conductivity of CuO-water based nanofluids with different dispersants. Part. Sci. Technol. 2019, 38, 1-9. [CrossRef] 